\title{
GENETIC POLYMORPHISM OF METABOLIC ENZYMES P450 (CYP) AS A SUSCEPTIBILITY FACTOR FOR DRUG RESPONSE, TOXICITY, AND CANCER RISK
}

\author{
Nada BOŽINA ${ }^{1,2}$, Vlasta BRADAMANTE², and Mila LOVRIĆ ${ }^{1}$ \\ Clinical Institute of Laboratory Diagnosis, Zagreb University School of Medicine and University Hospital Centre \\ Zagreb $^{1}$, Department of Pharmacology, Zagreb University School of Medicine ${ }^{2}$, Zagreb, Croatia
}

Received in June 2008

Accepted in April 2009

\begin{abstract}
The polymorphic P450 (CYP) enzyme superfamily is the most important system involved in the biotransformation of many endogenous and exogenous substances including drugs, toxins, and carcinogens. Genotyping for CYP polymorphisms provides important genetic information that help to understand the effects of xenobiotics on human body. For drug metabolism, the most important polymorphisms are those of the genes coding for CYP2C9, CYP2C19, CYP2D6, and CYP3A4/5, which can result in therapeutic failure or severe adverse reactions. Genes coding for CYP1A1, CYP1A2, CYP1B1, and CYP2E1 are among the most responsible for the biotransformation of chemicals, especially for the metabolic activation of pre-carcinogens. There is evidence of association between gene polymorphism and cancer susceptibility. Pathways of carcinogen metabolism are complex, and are mediated by activities of multiple genes, while single genes have a limited impact on cancer risk. Multigenic approach in addition to environmental determinants in large sample studies is crucial for a reliable evaluation of any moderate gene effect. This article brings a review of current knowledge on the relations between the polymorphisms of some CYPs and drug activity/toxicity and cancer risk.
\end{abstract}

KEY WORDS: cancer risk, cytochrome P450, drug metabolism, genotyping, pharmacogenomics, polymorphic allele, xenobiotics

The traditional toxicity assessment has been using descriptive means, finding links between chemicals in different doses and tissue pathology at the site of action, system-level toxicity, and overt mortality. It has been providing a framework for understanding the toxicity of a chemical. Progress in biological research calls for the understanding of the mechanisms of toxicity at the molecular level. Here the essential role is played by genomic information at the pharmacokinetic and pharmacodinamic level. For example, the genotype of an individual can significantly influence the disposition of a chemical, and determine their susceptibility to its toxicity (1). In addition, exposure to chemicals can result in different gene expression, which in turn can lead to different pharmacodynamic effects. The Human Genome Project (HUGO) has provided a number of genetic information that helps us understand the effects of xenobiotics on biological systems. New scientific fields have developed. Pharmacogenomics studies the role of gene variants in interactions between drugs and drug-exposed organisms (2-5). Ecogenetics investigates dynamic interactions between a specific individual genotype and different compounds from the environment such as industrial chemicals and nutrition products $(6,7)$. Toxicogenomics studies individual 
predisposition to carcinogenic, teratogenic, and other toxic effects of drugs and other xenobiotics (8). Integration of genomics into toxicological research can provide a better understanding of how various xenobiotics act in the human body (9).

Main proteins involved in xenobiotic disposition in the body are classified as either phase I (oxidative), or phase II (conjugative) metabolising enzymes, or phase III transporters involved in efflux mechanisms. The major enzymes of phase I metabolism are heme thiolate proteins of the cytochrome P450 superfamily (CYPs).

Phase I enzymes generate functional groups that may subsequently serve as a site for conjugation catalysed by phase II enzymes UDP-glucuronosyltransferases (UGT), Sulfotransferases (SULT), Glutathione Stransferases (GST), and N-acetiltransferases (NAT). These enzyme reactions are necessary fo a lipophilic compound to biotransform into a watersoluble product that can be excreted in urine. Phase III transporters like, P-glycoprotein (Pgp), multidrug resistanceassociated proteins (MRPs), and organic anion transporting polypeptide 2 (OATP2) are expressed in many tissues such as the liver, intestine, kidney, and brain, and play a crucial role in xenobiotic absorption, distribution, and excretion. Along with phase I and phase II enzyme induction/inhibition, pretreatment with different inducers or inhibitors has been shown to alter the expression of phase III transporters, with the final results of altered excretion of xenobiotics. Orphan nuclear receptors like pregnane X-receptor (PXR) and constitutive androgen receptor (CAR) are often termed "xenosensors". They interact with various exogenous drugs and toxins, and mediate cellular response to toxic insult by acting as transcription factors for the members of the secretory detoxification system, including efflux transporters and metabolic enzymes $(10,11)$. Exposure to phase I, phase II, and phase III inducers may trigger cellular stress response leading to increase in gene expression, which ultimately enhances the elimination and clearance of these xenobiotics.

Chemical carcinogenesis is a complex multistage process that includes three main steps: initiation, promotion, and progression. Each stage depends on a number of factors that can promote or prevent carcinogenesis. The genotoxic impact of carcinogen exposure is heavily influenced by a complex array of metabolic pathways. Carcinogenesis induced by genotoxic xenobiotics is related to polymorphisms of phase I and phase II enzyme systems responsible for metabolic activation/detoxification of carcinogenic substances. Along with carcinogen dose and exposure time, these factors influence the outcome of a malignant process. Carcinogenic agents are divided into direct carcinogens such as $\mathrm{N}$ nitrosoalkylurea, ethyl-and methylmethanesulfonate, $\mathrm{N}$-methyl-N-nitronitrosoguanidine, sulphur mustard, diepoxybutane, $\beta$-propiolactone, and ethyleneimine, and procarcinogens which are metabolised in the cell in two steps catalysed by various phase I and II enzymes. In the first step, procarcinogens are activated and converted into electrophilic derivatives. In the second step, metabolic products are neutralised by conjugation (12). The main activating enzymes include CYPs isoforms, and to a lesser degree, oxidases, hydroxylases, epoxygenases reductases, flavin-containing monooxygenases, peroxidases, dehydrogenases, hydrolases, and some other enzymes. Conjugation enzymes include epoxidases, acyltransferases, sulfotransferases, gluthationeS-transferases, UDP-glucuronyl transferases, and transaminases. For some carcinogens, second-stage reactions are a necessary intermediate step and a prerequisite to further activation.

The majority of currently known procarcinogens are hydrophobic CYP substrates (Table 1). Most hydrophobic substrates are polycyclic aromatic hydrocarbons (PAHs), polychlorinated biphenyls, and dioxin-like compounds. More hydrophilic compounds include nitrosoureas, aminoazo dyes, biphenyls, fluorenes, and heterocyclic amine (13). Some enzymes influence carcinogenesis indirectly i.e. by metabolising a number of endogenous compounds such as sex hormones, corticosteroids, cholesterol, bile acids, and retinoic acid. Mutations in the corresponding genes may promote carcinogenesis and progression of tumours (14). Habits like cigarette smoking, are yet another source of exposure relevant for cancer development in some tissues and organs such as large bowel, and lung. Estimations of cancer risk should always take into account the interplay between dietary habits, environmental exposure, and expression of particular isoforms of metabolic enzymes.

\section{CYTOCHROMES P450 (CYPs)}

\section{Overview}

Among the enzymes of phase I biotransformation, CYPs exhibit considerable catalytic diversity. This 
enzyme superfamily, existing in over 50 forms, is the most important enzyme system involved in the biotransformation of many endogenous and exogenous substances including drugs. CYPs are variably distributed in different tissues. Most can be found in the membrane of the endoplasmatic reticulum in the liver, although CYPs are found in almost all tissues and organs (intestine, lung, kidney, brain, lymphocytes, and placenta). Physiological substrates of these enzymes include steroids, fatty acids, prostaglandins, leukotrienes, and biogene amines, while xenobiotic substrates include drugs, herbal toxins and toxic chemicals from the environment. CYPs predominantly catalyse oxidative reactions, insertion of an atom from molecular oxygen into a substrate, i.e. a typical activating (or Phase I) reaction, serving as monooxygenases, oxidases and peroxidases, although they can act in reduction reactions too. CYPs are divided in three major groups. The first includes CYP families 5 to 51 with a high affinity for endogenous substrates, which have remained well conserved throughout evolution. The second group includes CYP families 1 to 3 , that have lower affinity for their substrates and have been less conserved evolutionarily. The third group includes CYP family 4 which metabolise fatty acids, related substrates, and some xenobiotics. CYP families 1 to 3 are responsible for $70 \%$ to $80 \%$ of all phase I- dependent metabolism of clinically used drugs (9), and participate in the metabolism of a huge number of xenobiotic chemicals (Table 2) (15). Most of the enzymes in CYP families 1 to 3 exhibit interindividual variability in catalytic activity. This is either due to genetic polymorphisms or to variability in expression levels.

Each CYP isoform has its own set of metabolised substrates. The same xenobiotic can be metabolised by different isoforms into similar or different metabolic products. For enzymes belonging to CYP families 1 to 4 overlapping substrate specificity is known.

The most important enzymes for drug metabolism are CYP2C9*, CYP2C19, CYP2D6 and CYP3A4, whereas the most important isoforms responsible for the biotransformation of chemicals and especially for the metabolic activation of pre-carcinogens are CYP1A, CYP1A2, CYP1B1, CYP2A6, CYP2E1 and again CYP3A4. In CYP families 2 and $3 \mathrm{HUGO}$ has found new genes like CYP2R1, CYP2S1, CYP2U1 and $C Y P 3 A 43$. Their function and importance are still investigated.

\footnotetext{
Enzymes are written in capital letters, and coding genes in italics
}

There is no apparent relationship between the amount of hepatic CYPs and their relative importance for drug metabolism. This might indicate that highly expressed CYPs play an important role in food metabolism and a relatively minor role in drug metabolism.Most CYP enzymes are preferentially expressed in the centrilobular area of the liver (16). This has toxicological implications, as the centrilobular area is more sensitive to damage by drugs and ethanol, which are CYP substrates.

Most CYPs involved in the biotransformation of xenobiotics are inducible (17). An exception is CYP2D6 in which multiple gene copies are responsible for increased detoxifying potential of the enzyme (18). Induction is an important adaptive reaction against environmental toxins from the past. CYP expression can be controlled at the transcriptional, mRNA, translational and posttranslational levels. Transcriptional control is highly important and three crucial cytosolic receptors detect the concentration of environmental xenobiotics, namely the pregnane $\mathrm{X}$-receptor (PXR), constitutive androgen receptor (CAR) and aryl hydrocarbon receptor (AhR). AhR regulates CYP1A1, CYP1A2 and CYP2S1; PXR regulates $\mathrm{CYP} 2 \mathrm{C} 9$ and $\mathrm{CYP} 3 \mathrm{~A} 4$ and $\mathrm{CAR}$ regulates CYP2B6, CYP2C9, and CYP3A4. Activation of CYPs as well as phase II and phase III proteins is stimulated by increased cellular amounts of environmental xenobiotics, which may result in higher protein expression and subsequently in lower amounts of xenobiotics. It is evident that these transcriptional factors are involved in the control of most human drug metabolising CYPs.

Polymorphisms of receptors CAR, PXR, and AhR have also been described in literature. For example more than 10 mutations in the AhR gene have been identified to be able to modulate CYP activity (19, 20).

Of special interest are interaction studies in human liver microsomes using CYP- specific inhibitors, which give important information of the role of CYPs in the biotransformation of different xenobiotics (21-26). In vitro systems can reliably predict enzyme specificity and drug clearance, provided that the drug is not metabolised in phase II reactions. In addition, knockout mouse and transgenic models provide many advantages in studying physiological and toxicological roles of different CYPs.

Herbs with the potential to significantly modulate the activity of drug-metabolising enzymes, notably CYPs and drug transporter P-glycoprotein, include 
garlic (Allium sativum), ginkgo (Ginkgo biloba), echinacea (Echinacea purpurea), ginseng (Panax ginseng), St John's wort (Hypericum perforatum), kava (Piper methysticum), and grapefruit (Citrus paradisi). All of these products can participate in pharmacokinetic interactions (27-29).

\section{Cytochrome P450 genes}

The nomenclature for cytochrome P450 (CYPs) uses designation "CYP" followed by a number indicating the gene family (for a gene to be in the same family, its aminoacid sequence should be identical in over $40 \%$ ), followed by a letter indicating the subfamily (over $55 \%$ of identical amino acid sequence) and the gene number (30). The same gene number means that genes have the same function and are highly conserved. Human genome sequence has revealed about 107 human P450 genes: 59 active and about 48 pseudogenes (31). The majority of hepatic drug metabolising enzymes are polymorphic. A gene is considered to be polymorphic when the frequency of a variant allele in normal population is at least $1 \%$.
Genes encoding xenobiotic metabolism (CYP1-3) differ in their characteristics from genes important for the metabolism of predominantly endogenous compounds (CYP4-CYP51). The first group includes a number of pseudogenes, that is, genes encoding chemical metabolism that have been inactivated as a result of adaptation to the environment. In CYP families 1 to 3, the majority of genes are also functionally polymorphic, with the exception of CYP1A1, CYP2E1, and CYP $3 A 4$, which are relatively well-conserved. The reason for this conservation might be that these enzymes have some endogenous substrates in addition to the exogeneous. Pseudogenes are also present in some CYPs involved in endogenous metabolism $(C Y P 21 P)$, but there is significantly less variability than in CYP families 1 to 3. Inter-ethnic and inter-racial differences in frequencies of polymorphic gene variants are also worth noting (32).

Genetic polymorphism is an important reason for variations in drug response of the human body. In terms of drug metabolism, there are four specific phenotypes that can be determined by either

Table 1 Participation of various human cytochrome P450 enzymes in the metabolic activation of pre-carcinogenes (9)

\begin{tabular}{|c|c|c|c|c|c|}
\hline CYP1A1 & CYP1A2 & CYP1B1 & CYP2A6 & CYP2E1 & CYP3A4 \\
\hline \multirow[t]{11}{*}{ Benzo(a)pyrene } & $\begin{array}{l}\text { 2-Acetyl- } \\
\text { aminofluorene }\end{array}$ & Benzanthracene & Aflatoxin B1 & Benzene & Aflatoxin B1 \\
\hline & 4-Amino-biphenyl & Benzo(a)pyrene & DEN & Chloroform & Aflatoxin G1 \\
\hline & GluP-1 & DMBA & IQ & DEN & 6-Amino-chrysene \\
\hline & IQ & 1-Ethynyl-pyrene & MOCA & Ethyl carbamate & Benzo(a)pyrene \\
\hline & MeIQ & $\begin{array}{l}\text { 3-Methyl- } \\
\text { cholantrene }\end{array}$ & MeIQ & Methylene chloride & 1-Nitropyrene \\
\hline & MeIQx & Oestradiol & NNK & $\begin{array}{c}\text { N-nitroso- } \\
\text { dimethylamine }\end{array}$ & Oestradiol \\
\hline & $\begin{array}{l}\text { N-nitroso- } \\
\text { diethylamine }\end{array}$ & & & N-nitroso-nicotine & Senecionine \\
\hline & NNK & & & NNK & Stergmato-cystine \\
\hline & PhIP & & & Styrene & \\
\hline & Trp P-2 & & & Vinyl chloride & \\
\hline & & & & Vinyl bromide & \\
\hline
\end{tabular}

DMBA dimethylbenzanthrazene,

DEN 3-amino-1-methyl-5H-pyrido(4,3-b)indole,

$D M N$ N-nitrosodimethylamine,

GluP-1 2-amino-6,-methyl-dipyrido-(1,2-a:3',2'-d)imidazole,

IQ 2-amino-3-methylimidazo(4,5-f)quinoxaline,

MeIQ 2-amino-3,4 dimethylimidazo(4,5-f)quinoxaline,

MOCA 4,4'-methylene-bis(2-choloroaniline),

NNK 4-(methylnitrosoamino)-1-(3-pyridyl)-1-butanone

PhIP 2-amino-1-methyl-6 phenylimidazo(4,5-b)pyridine,

Trp P-2, 2-aminodipyrido(1,2-a: 3',2'-d)imidazole 
phenotyping or genotyping: a poor metaboliser (PM), intermediate metaboliser (IM), extensive metaboliser (EM), and ultrarapid metaboliser (UM). Phenotyping involves administration of a test drug whose metabolism dependens only on the enzyme involved, followed by the estimation of the metabolic ratio (MR, defined as the ratio of the parent/unchanged drug to its metabolite measured in serum or urine). Drug concentration is often measured using methods like HPLC, GC-MS or LC-MS (33). Phenotyping is very useful in pharmacokinetic studies, as it reveals the extent of drug-drug interactions or impairments in drug biotransformation. On the other hand, phenotyping has several disadvantages, which include complicated test protocols, risk of adverse drug reactions, and the risk of incorrect phenotype designation due to coadministration of drugs or confounding effects of a disease. Genotyping involves identification of defined genetic mutations that result in specific drug metabolism. These mutations can be genetic alterations that lead to overexpression (gene multiplication), absence of an active protein product (null allele), or production of a mutant protein with diminished catalytic capacity (inactivating allele). Genotyping is predominantly based on polymerase chain reaction (PCR) methods. An important technological advance in genetic testing is the DNA microarray, which allows for simultaneous testing of thousands of DNA sequences (34).

A poor metaboliser lacks active allele and may experience more adverse events at usual doses due to reduced metabolism and increased drug concentration. If individuals lacking the active allele receive a prodrug, they may not respond due to a lower-than-expected concentration of the active metabolite. Individuals with intermediate metabolic phenotype are homozygous for two reduced activity alleles or are heterozygous for an inactive allele. They may experience some, or a lesser degree of the consequences of the poor metaboliser. Extensive metaboliser has two fully active alleles and shows the expected response to a standard dose. Ultraextensive metabolisers are individuals with more than two copies of active gene. They may not reach therapeutic concentrations at usual, recommended drug doses due to increased metabolism. When a prodrug is administered, they may experience adverse effects due to higher-than-expected concentrations of active metabolite.

Adverse drug reactions (ADRs) pose substantial difficulties in drug treatment and drug development. It has been estimated that ADRs cause more than
100,000 deaths a year in the US alone (35), up to $7 \%$ of all hospital admissions in the UK, and $13 \%$ of all admissions to internal medicine clinics in Sweden (36). ADR burden in the US is about US\$ 100 billion a year (35).

The knowledge that enzyme systems take the central role in developing ADRs is crucial for drug therapy. About $59 \%$ of drugs cited in ADR studies are metabolised by polymorphic phase I enzymes, and among those CYPs account for $86 \%$. By contrast, only $20 \%$ of drugs that are non-polymorphic enzyme substrates are included in ADR reports (37). Clinically the most important polymorphisms are of the $C Y P 2 C 9$, CYP2C19, and CYP2D6 genes.

Understanding of the genetics and biology of phase I and II enzymes can help to predict a lot of events related to the metabolic activation of carcinogens and the relative risk for toxic or carcinogenic effects of other xenobiotics. Table 3 summarises the functional profile of polymorphic CYPs involved in the biotransformation of xenobiotics.

This article has focused on some of phase I CYPs participating in the metabolism of xenobiotics.

\section{CYPIAI}

CYP1A1 is mainly expressed in extrahepatic organs, especially in epithelial tissues. A relevant feature of this enzyme is its ability to catalyse the first step in the metabolism of polycyclic aromatic hydrocarbons (PAHs, also present in tobacco smoke), which may lead to a formation of electrophilic carcinogenic molecules. CYP1A1 also catalyses oxidation of several xenobiotic chemicals such as 7-ethoxyresorufin, theophylline, caffeine, 7-ethoxycoumarin, and chlorzoxazone, and of endogenous chemicals such as $17 \beta$-estradiol and estrone (38). CYP1A1 polymorphism affects both CYP1A1 regulation and structure. Regulation begins with the binding between the inducing agent (xenobiotic substrate to be metabolised) and intracellular arylhydrocarbon receptor (AhR). This high-affinity receptor is associated with high CYPIA1 inducibility. The AhR complex can also interact with the activity of a variety of components of the endocrine system (tumour necrosis factor $\alpha$, epidermal growth factor receptor, or glucocorticoid and estrogen receptors). There are genetic polymorphisms in the $A h R$ gene in humans, and interindividual differences in AhR phenotype have been observed (39). About one-tenth of the population have the high-affinity AhR phenotype and highly inducible CYP1A1 (40). 
More than 11 alleles of CYP1A1 have been identified, (41) of which $C Y P 1 A 1 * 2 B, * 2 C, * 3, * 4, * 5$, $* 6, * 7, * 8, * 9, * 11$ show amino acid changes. However, it is unclear whether these amino acid changes alter catalitic activities in oxidation of xenobiotics, including PAHs. There is evidence of race-related differences in the genetic polymorphism of $C Y P 1 A 1(42,43)$; $C Y P 1 A 1 * 2 A$ and $C Y P 1 A 1 * 2 C$ variant alleles are more frequent in Asian (Japanese) than Caucasian populations. CYP1A1*3 allele is specific for African blacks, and has not been found in either Asian or Caucasian populations. This polymorphism has been reported to increase the risk for African-Americans of adenocarcinoma (44). Other studies do not support this finding (45). Most investigations on cancer risk arising from CYP1A1 polymorphism have studied the effects of modified CYP1A1 in association with deficient phase II enzymes (predominantly GST) and other gene variants that affect activation and detoxification of CYP1A1 substrates (46). GST detoxifies many of activated carcinogens that are produced during the Phase I metabolism. There are numerous conflicting epidemiological studies addressing correlations between cytochrome CYP1A1 genetic polymorphisms and lung cancer susceptibility, with associations plausibly linked to alterations in carcinogen bioactivation. Some studies showed that a combination between overexpressed CYP1A1 and deficient GST highly increased lung cancer risk after exposure to PAHs $(47,48)$. Moreti at al. (49) published results of a cross-sectional study that aimed to evaluate whether genetic polymorphisms for CYP1A1, EPHX (epoxide hydrolase), and GSTMI genes that affect PAH activation and detoxification might influence the extent of primary DNA damage in PAH-exposed workers. They showed that molecular epidemiology, that is cross-sectional study of genotoxicity biomarkers, can help identify common genetic risk markers and associate effects with measured exposure data. Shah et al. (50) reported that lung cancer risk increased two to four times in patients carrying the genotype combination of CYP1A1*2A and GSTM1 (deletion polymorphisms), which suggests that lung cancer susceptibility may depend on interactions between genes. In the same study, tobacco smoking or chewing and alcohol consumption were also found to interact with CYP1A1 genotypes in terms of increased risk, which further confirmed a role of gene-environment interaction in the development of lung cancer.

Other published data (51) also gave evidence of gene-gene interactions which include CYP1Al in lung carcinogenesis. A population-based study (52) found that Caucasians but not African Americans with $\mathrm{IIe} / \mathrm{Val}(\mathrm{CYP} 1 \mathrm{Al} * 2 \mathrm{C})$ genotype were at a lower risk of developing lung cancer than those with lle/lle $(* 1 / * 1)$ genotype, after adjusting for age at diagnosis, sex, years of smoking and family history of cancer. A recent study (53) pointed to a potential role of oestrogen in lung cancer susceptibility. Authors evaluated $11 S N P S$ in genes involved in tobacco and oestrogen metabolism $(C Y P 1 A 1 * 2 A, C Y P 1 A 1 * 2 C$, CYP1B1*3, CYP17, CYP19A1, XRCC1 Gln(399)Arg, COMT Val(158)Met, NQO1 Pro(187)Ser, GSTM1, GSTT1, and GSTP1 Ile(105)Val. The study included 504 women aged 18 to 74 , diagnosed with non-small cell lung cancer (NSCLC) and 527 controls. Lung cancer risk associated with individual $S N P$ was established for GSTP1 ( $A$ allele) and XRCC1 (A/A genotype) in white women smokers and for $C Y P 1 B 1$ ( $G$ allele) in black women smokers. White women smokers carrying two risk genotypes at the following loci - CYP17 and GSTM1, COMT and GSTM1, CYP17 and GSTT1, XRCC1 and GSTP1, CYP1B1 and $X R C C 1$, and $C O M T$ and $X R C C 1$ - were at a higher risk of lung cancer than individuals not carrying risk alleles at these loci. This suggests that even the most parsimonious model of lung cancer risk assessment in white smoking women should include age, family history of lung cancer, history of chronic lung disease, pack-years, BMI, XRCC1 A/A genotype, GSTM1 null, and $C O M T A / G$ or $G / G$ genotype. These findings also support the need for continued study of oestrogen in relation to lung cancer risk.

Shi et al. (54) summarised data from 46 studies and conducted a meta-analysis of CYPIAl and GSTM1 polymorphisms and lung cancer risk in Chinese populations. They confirmed the association between the CYP1A1*2C allele variant and GSTM1 with increased risk of lung cancer. For the same polymorphisms, an eightfold increase in susceptibility to lung cancer was demonstrated in a north Indian population (55). A Korean group (56) investigated the association between $C Y P 1 A 1 * 2 C, C Y P 1 B 1 * 3$, GSTP1 Ile105 Val, and MPO G-463A polymorphisms and lung cancer risk in never-smoking Korean women. They found $C Y P 1 A 1 * 2 C$ polymorphism associated with a significantly lower risk of lung adenocarcinoma. However, a combination of risk gene variant $C Y P 1 B 1 * 3$ with $C Y P 1 A 1 * 2 C$ was associated with a higher risk of lung adenocarcinoma as well as of overall lung cancer. Variability assessment of tobacco metabolism, oestrogen metabolism, and 
DNA repair pathways could be useful in developing more predictive models for individual cancer risk in connection with CYP1A1 polimorphism.

Other published data (57) suggest that CYP1A1 polymorphisms could be useful predictors of breast cancer risk as well as of some tumour characteristics. Variant allele $6235 \mathrm{C}$ carriers at the 3' noncoding region, and variant allele $462 \mathrm{Val}$ carriers at the codon 462 polymorphism showed a significantly reduced breast cancer risk than noncarriers. Another study found that carriers of CYP19 (TTTA)7($3 b p$ ) and CYP1A1 C6235T polymorphisms had a significantly increased risk of ER-positive breast cancers, which could be a useful information in

Table 2 General properties of human cytochrome P450 enzymes in families 1-3 (9)

\begin{tabular}{|c|c|c|c|c|}
\hline Enzyme & Marker substrate reaction & $\begin{array}{l}\text { Substrate } \\
\text { specificity }\end{array}$ & $\begin{array}{l}\text { Main tissue } \\
\text { localisation }\end{array}$ & Comments \\
\hline CYP1A1 & EthoxyresorufinO-deethylation & $\begin{array}{l}\text { Pre-carcinogens, } \\
\text { PAHs }\end{array}$ & Extrahepatic & $\begin{array}{l}\text { Inducible by PAHs, } \\
\text { endogenous role in cell } \\
\text { growth }\end{array}$ \\
\hline CYP1A2 & $\begin{array}{l}\text { Phenacetin O-deethylation } \\
\text { ethoxyresorufin O-deethylation }\end{array}$ & $\begin{array}{l}\text { Aromatic amines, } \\
\text { PAHs }\end{array}$ & Liver & $\begin{array}{l}\text { Inducible by PAHs and } \\
\text { some drugs }\end{array}$ \\
\hline CYP1B1 & Estradiol-4-hydroxylation & $\begin{array}{l}\text { DMBA, } \\
\text { oestradiol }\end{array}$ & Extrahepatic & $\begin{array}{l}\text { Inducible by PAHs, high } \\
\text { affinity for some PAHs }\end{array}$ \\
\hline CYP2A6 & Coumarin 7-hydroxylation & Nicotine & Liver & $\begin{array}{l}\text { The major nicotine oxidase, } \\
\text { active on some drugs and } \\
\text { carcinogens }\end{array}$ \\
\hline CYP2A13 & Coumarin 7-hydroxylation & & $\begin{array}{l}\text { Olfactory } \\
\text { mucosa }\end{array}$ & \\
\hline CYP2C8 & Taxol hydroxylation & & Liver & $\begin{array}{l}\text { Might have a role in hepatic } \\
\text { drug metabolism }\end{array}$ \\
\hline $\begin{array}{l}\text { CYP2C9 } \\
\text { see Table } 4\end{array}$ & $\begin{array}{c}\text { Tolbutamide methylhydroxylation, } \\
\text { losartan hydroxylation, S-warfarin } \\
\text { 7-hydroxylation }\end{array}$ & Many drugs & Liver & $\begin{array}{l}\text { Very important for drug } \\
\text { metabolism }\end{array}$ \\
\hline CYP2C18 & $?$ & Some drugs & Extrahepatic & Highly polymorphic \\
\hline $\begin{array}{l}\text { CYP2C19 } \\
\text { see Table } 5\end{array}$ & $\begin{array}{c}\text { S-mephenytoin } \\
\text { 4-hydroxylationomeprazole } \\
\text { 5-hydroxylation }\end{array}$ & Many drugs & Liver & $\begin{array}{l}\text { Highly polymorphic, } \\
\text { very important for drug } \\
\text { metabolism }\end{array}$ \\
\hline $\begin{array}{l}\text { CYP2D6 } \\
\text { see Table } 6\end{array}$ & $\begin{array}{l}\text { Dextromethorphan O-deethylation; } \\
\text { bufuranol 1-hydroxylation, } \\
\text { debrisoquine 4-hydroxylation }\end{array}$ & Many drugs & Liver & $\begin{array}{l}\text { Very important for drug } \\
\text { metabolism }\end{array}$ \\
\hline CYP2E1 & Chlorzoxazone 6-hydroxylation & $\begin{array}{l}\text { Solvents, } \\
\text { many drugs, } \\
\text { precarcinogens }\end{array}$ & Liver & $\begin{array}{l}\text { The main enzyme which } \\
\text { metabolises organic } \\
\text { solvents, highly inducible }\end{array}$ \\
\hline CYP2F1 & & & Lung & Active? \\
\hline CYP2J2 & Arachidonic acid hydroxylation & Fatty acids & Extrahepatic & \\
\hline CYP2R1 & Vitamin D25 hydroxylase & Vitamin D & Extrahepatic & $\begin{array}{l}\text { The function recently } \\
\text { revealed }\end{array}$ \\
\hline CYP2S1 & Trans-retinol oxidation & $\begin{array}{l}\text { Small aromatic } \\
\text { hydrocarbons }\end{array}$ & Extrahepatic & $\begin{array}{l}\text { Inducible by UV-light in } \\
\text { skin }\end{array}$ \\
\hline $\begin{array}{l}\text { CYP3A4 } \\
\text { see Table } 7\end{array}$ & $\begin{array}{l}\text { Testosterone } 6 \beta \text {-hydroxylation, } \\
\text { midazolam 1'-hydroxylation, } \\
\text { erythromycin N-demethylase }\end{array}$ & $\begin{array}{l}\text { Many drugs, } \\
\text { pre-carcinogens, } \\
\text { dietary } \\
\text { components }\end{array}$ & Liver, intestine & $\begin{array}{l}\text { The most important P450 in } \\
\text { drug metabolism }\end{array}$ \\
\hline CYP3A5 & Same as CYP3A4 & $\begin{array}{l}\text { Similar as } \\
\text { CYP3A4 }\end{array}$ & Liver, intestine & $\begin{array}{l}\text { Expressed in some } \\
\text { individuals }\end{array}$ \\
\hline CYP3A7 & Same as CYP3A4 & $\begin{array}{l}\text { Similar as } \\
\text { CYP3A4 }\end{array}$ & Liver, intestine & $\begin{array}{l}\text { Mainly expressed in fetal } \\
\text { liver }\end{array}$ \\
\hline CYP3A43 & Not known & Not known & Liver & Tiny expression, active? \\
\hline
\end{tabular}


screening for chemoprevention with tamoxifen (58). Some studies (59) confirmed earlier reports that $C Y P 1 A 1 * 2 C$-containing genotypes modified the association between PCB exposure and risk of breast cancer. They presented additional evidence suggesting that $C Y P 1 A 1 * 3$-containing genotypes modified the effects of $\mathrm{PCB}$ exposure among African American women. A Russian group (60) estimated the frequency of CYP1A1, CYP1A2, CYP1B1, CYP19, and SULT1A1 allele variants in a female population of the Novosibirsk district and their associations with higher risk of breast (BC), ovarian (OC), and endometrial (EC) cancers. It found significant differences in allele distributions for $C Y P 1 A 1 * 2 A$ polymorphism between patients with $\mathrm{BC}$ and controls. Furthermore, significant differences were found in the allele and genotype distributions for $C Y P 1 A 2 * 1 F$ polymorphism between patients with $\mathrm{BC}$ and $\mathrm{OC}$. The frequency of a mutant CYP19 heterozygote genotype $C / T$ was higher in patients with $\mathrm{OC}$ and EC than in healthy women. These results support the hypothesis that the susceptibility gene of oestrogenmetabolising enzymes may involve different risk of hormone-dependent cancers in women. Report on the association between a combination of CYPIA1 and $S U L T$ gene polymorphisms and endometrial cancer suggests that decreased variant allele $C Y P 1 A 1 * 2 A$ and increased variants of SULT1A1(Arg213His, $14 A / G, 85 C / T)$ and SULT1E1-64G/A may be risk factors for endometrial cancer in Caucasians (61). Oestrogens have also been proposed to act as tumour promoters and inducers of hepatocarcinogenesis. We observed a significant association between the risk of hepatocellular carcinoma and the polymorphisms of the oestrogen receptor alpha (ESRI) gene. A Chinese group (62) confirmed the association between hepatocellular carcinoma (HCC) and four variants of CYP1A1 in a study that included 1006 pathologically confirmed HCC patients and 1015 cancer-free controls from Han population. Another Chinese study (63) could not confirm these results and concluded after stratification by common confounding factors of

Table 3 Functional importance of polymorphism in human P450 enzymes involved in xenobiotic metabolism

\begin{tabular}{|c|c|c|c|c|}
\hline Enzyme & Substrate & $\begin{array}{l}\text { Frequency of } \\
\text { variant alleles }\end{array}$ & Functional effects & $\begin{array}{c}\text { Clinical } \\
\text { effects }\end{array}$ \\
\hline CYP1A1 & Carcinogens & Relatively high & Unproven & No \\
\hline CYP1A2 & $\begin{array}{l}\text { Many drugs } \\
\text { Carcinogens }\end{array}$ & High & $\begin{array}{l}\text { Polymorphic induction } \\
\text { Rare allels yielding less expr }\end{array}$ & Yes \\
\hline CYP1B1 & $\begin{array}{l}\text { Carcinogens } \\
\text { Oestrogens }\end{array}$ & $\begin{array}{l}\text { Rare null alleles } \\
\text { Frequent missense } \\
\text { mutations }\end{array}$ & 7 haplotypes with similar activity & $\begin{array}{l}\text { Yes, } \\
\text { glaucoma }\end{array}$ \\
\hline CYP2A6 & $\begin{array}{l}\text { Nicotine, drugs, } \\
\text { carcinogens }\end{array}$ & $\begin{array}{l}\text { High in orientals } \\
\text { Les frequent in } \\
\text { Caucasians }\end{array}$ & Nicotine metabolism & \\
\hline CYP2B6 & Many drugs & Relatively low & Reduced drug metabolism & Yes \\
\hline CYP2C8 & Some drugs & High & Taxol metabolism & Yes \\
\hline $\begin{array}{l}\text { CYP2C9 } \\
\text { See Table } 4\end{array}$ & Many drugs & Relatively low & Very significant & Yes \\
\hline $\begin{array}{l}\text { CYP2C19 } \\
\text { See Table } 5\end{array}$ & Many drugs & High & Very significant & Yes \\
\hline $\begin{array}{l}\text { CYP2D6 } \\
\text { See Table } 6\end{array}$ & Many drugs & Very significant & Yes & Yes \\
\hline CYP2E1 & $\begin{array}{c}\text { Carcinogens, } \\
\text { solvents, some drugs }\end{array}$ & High & Not shown & No \\
\hline $\begin{array}{l}\text { CYP3A4 } \\
\text { See Table } 7\end{array}$ & $\begin{array}{l}\text { Many drugs } \\
\text { Carcinogens }\end{array}$ & Low & No importance of polymorphism & No \\
\hline CYP3A5 & Many drugs & High & No expression & No \\
\hline
\end{tabular}


hepatocellular carcinoma, that the polymorphisms in enzymes involved in the biogenesis (CYP17,CYP19), bioavailability (CYP1A1, CYP1B1), and degradation (catechol-O-methyltransferase) of oestrogens were not associated with the risk of hepatocellular carcinoma. Furthermore, no signs of gene-gene interactions were observed for any of the combinations of the seven polymorphisms. Recent findings (64) suggest that common variants in hormone-related genes contribute to the risk of biliary tract cancers and stones, possibly by modulating hormone metabolism. Genotyping 18 SNPs in 9 genes involved in steroid hormone biosynthesis, metabolism, and transport revealed that CYP1A1 IVS1 + 606 (rs2606345) T allele had a possible impact on gallbladder and bile duct cancers, while the CYP1A1 Ex7+131 (rs 1048943) $G$ allele was associated with ampulla of Vater cancer.

Other studies partly support that polymorphic variations in CYPlAl $(* 2 A, * 2 C, * 4)$ may play a role in colorectal cancer (65-67).

\section{CYP1A2}

CYP1A2 is mainly expressed in the liver. The level of CYP1A2 protein is $10 \%$ to $15 \%$ of total $\mathrm{P} 450$ in human adult liver. Expression levels vary about 40 times between individuals.

CYP1A2 catalyses metabolic activation of a variety of aryl- and heterocyclic amines such as 2aminoanthracene and 2-acetylaminofluorene (Tables 1 and 2). CYP1A2 catalyses the activation of PAHdiols to reactive metabolites at much slower rates than CYP1A1 and 1B1. CYP1A2 oxidizes other xenobiotic chemicals including acetaminophen, antipyrine, caffeine, 7- ethoxyresorufin, lidocaine, phenacetin, theophylline, and $R$-warfarin. More than 16 CYP1A2 polymorphic alleles have been identified (41). Alleles CYP1A2*2-*16 show amino acid changes $(68,69)$. In vitro studies revealed that the CYP1A2*11 allele variant decreases 7 -ethoxyresorufin $O$-deethylation activity (70) The CYP1A2*7 allele contains a splicing defect $(G 3534 A)$, which is responsible for a decrease in clozapine (an atypical antipsychotic) concentrations in vivo (69). $C Y P 1 A 2 * 1 F(-163 C>A)$ is associated with a high inducibility of CYP1A2 in smokers. Some reports (71) described cases where smoking patients did not respond to clozapine treatment and had low drug plasma levels at normal doses. A discontinuation in smoking might lead to elevated clozapine plasma concentrations and severe side effects (72). As schizophrenic patients have a high frequency of smokers and a high frequency of the $-163 C>A$ polymorphism, CYP1A2 genotyping could have important clinical implications. Reports described patients with $C Y P 1 A 2 * 1 F C C$ genotype treated for rheumatoid arthritis, who had a 9.7 times higher risk of overall leflunomide-induced toxicity than did the carriers of the $C Y P 1 A 2 * 1 F A$ allele (73). It is not fully understood whether CYP1A2 gene polymorphism relates to cancer susceptibility in humans. Some findings indicate that the association between cigarette smoking and colorectal carcinogenesis can be modified by the CYP1A2 genotype (74). Significant associations were found between the $C Y P 1 A 2 * 1 F$ and the risk of colorectal adenomas (75). Aromatic amines, $\mathrm{N}$-nitroso compounds and heterocyclic amines are suspected human pancreatic carcinogens. Study (76) results of association between the interaction of the CYP1A2, SULT1A1 and NAT gene polymorphisms with smoking and dietary mutagen intake in modifying pancreatic cancer risk revealed that $C Y P 1 A 2$ and NAT1 genotypes exhibited significant interactions with heavy smoking in women, but not in men. These data indicate a sex-specific susceptibility to tobacco carcinogen and dietary mutagen exposure in pancreatic cancer. They are in agreement with other published data (77). Some reports suggest that the $C Y P 1 A 2 * 1 F$ polymorphism has an important role in lung carcinogenesis, especially in squamous cell carcinoma among smokers (78). Ninety-five percent of caffeine is metabolised by cytochrome CYP1A2, and caffeine induce the enzyme. A common $A$ to $C$ polymorphism at position 163 in the CYP1A2 gene has been associated with decreased enzyme inducibility and enzymatic activity, resulting in the slower metabolism of caffeine (79-81). Some studies reported that among breast cancer susceptibility gene (BRCAl) mutation carriers, the consumption of caffeinated coffee was associated with a significant reduction in breast cancer risk (82). Another study indicated that CYP1A2 genotype did not affect breast cancer risk. However, among women with at least one variant $C$ ( $A C$ or $C C$, at position 163), those who consumed coffee had a $64 \%$ lower breast cancer risk than women who never consumed coffee (83).

Increased risk of myocardial infarction with increasing coffee consumption has been reported among carriers of the variant $C$ of the CYP1A2 gene (84). The authors attributed this to the prolonged presence of caffeine in the circulation among the slow metabolisers due to lower enzyme inducibility.

\section{CYP1B1}

CYP1B1 is expressed in the endoplasmatic reticulum of extrahepatic organs, predominantly in 
the steroidogenic tissues of the uterus, breast, ovary, testis, prostate and adrenal gland. It is also expressed in many other extrahepatic tissues including the lung, kidney, thymus, spleen, brain, heart, colon and intestine. Higher levels are found in a wide range of human cancers including cancers of the skin, brain, testis (85) and breast (86). CYP1B1 converts oestrogen to 4-hydroxylated metabolites (87) that may initiate breast cancer in humans (88). The enzyme also plays an important role in activating diverse procarcinogens including PAHs, aryl and heterocyclic amines and nitroarenes to reactive metabolites that cause DNA damage (Table 1) $(89,90)$.

More than 26 polymorphisms of CYP1B1 have been identified in humans; 19 of these variants show amino acid changes (41). The null allele of CYP1BI has been associated with hereditary glaucoma (91). The role of allelic variants in enzyme activity and their association with different forms of cancers have not yet been fully understood, and literature reports conflicting results. The complexity of haplotype distribution and relatively small functional effects indicate that CYP1B1 polymorphism alone does not significantly affect cancer risk associated with either lifelong smoking or lifelong exposure to polyaromatic hydrocarbons or oestradiol. New data suggest that combined polymorphisms in the CYP1B1 and phase II metabolic enzymes (GST, NAT), which are responsible for metabolic activation/detoxification of oestrogen and environmental carcinogens, could be susceptibility factors associated with cancer risk. CYP1B1 and GST polymorphisms in some studies were found significant in the aetiology of breast cancer, especially in women before the age of 60 (92). Stratified analyses demonstrated significant interactions in younger Caucasian women with the $119 S S$ variant of the CYP1B1*2 allele, $(A 119 S$ aminoacid change), and in younger African-American women with the GSTT1 null allele genotype. This trend was also found in Caucasian women with a history of smoking and at least one 114-valine allele at GSTP1. In Caucasian women, combined genotype variants GSTP1-105IV/VV(Ile105Val) and $C Y P 1 B 1 * 2,119 A A$ resulted in a nearly twofold increase in risk, and the combination of three genotype variants GSTP1 105IV/VV, CYP1B1 119AS/SS and GSTT1 null resulted in an almost fourfold increase in risk. Data also reveal that polymorphisms in phase I (CYP1B1) and phase II (GSTM1, GSTT1, GSTP1) enzymes may enhance the occurrence of mutations at critical tumour suppressor genes, such as $p 53$ (93). Since CYP1B1 belongs to a multitude of genes regulated by the oestrogen receptor alpha (ERalpha) expression, it is of interest to know whether CYP1B1 polymorphisms have an impact on the ERalpha status of breast cancer. Some authors observed a significant association between the homozygous variant $C Y P 1 B 1$ $1358 G G$ (increase CYP1B1 enzymatic activity) and negative ERalpha status. They also observed an association between CYP1B1 1358GG and progesterone receptor negative status $(\mathrm{p}=0.015)(94)$. The association between the cytochrome $C Y P 1 B 1 * 3$ allele and breast cancer was assessed (95) through a meta-analysis of all published case-control studies and a pooled analysis of both published and unpublished case-control studies from the Genetic Susceptibility to Environmental Carcinogens (GSEC) database. No association between $C Y P 1 B 1 * 3$ and breast cancer was observed in Asians, an inverse association was observed in populations of mixed/African origin, and the pooled analysis suggested a possible association in Caucasians, with effect modification across age categories. Authors suggested that the observed effect of age on the association in Caucasians indicates a

Table 4 Important drugs which are substrates of enzyme CYP2C9

\begin{tabular}{ll}
\hline Drug groups & Drugs \\
\hline Angiotensin II & losartan, irbesartan,valsartan \\
receptor blockers & tolbutamide, glipizide \\
Antidiabetics & warfarin \\
Anticoagulants & phenytoin \\
Anticonvulsants & metronidazole, sulphamethoxazole \\
Antimicrobials & celecoxib, diclofenac, ibuprofen, indomethacin, naproxen, tenoxicam \\
Nonsteroidal & \\
antiinflammatory drugs & amitriptyline, fluoxetine \\
Psychotropic drugs &
\end{tabular}


need for further investigation of the role of $C Y P 1 B 1 * 3$ in oestrogen metabolism according to age, ethnicity, and menopausal status.

Other studies (96) provided some support for polymorphic variation in $C Y P 1 A 2$ and $C Y P 1 B 1$ playing a role in colorectal cancer susceptibility. These authors also pointed out the importance of gene-environment interactions to be included in such studies to obtain reliable information about carcinogen exposure and diet. There are reports (97) on significant differences in the distribution of variant alleles $C Y P 1 B 1 * 2$ between patients with head and neck squamos cell carcinoma (HNSCC) and controls. Furthermore, data indicated a several-fold increase in the risk of HNSCC in patients with the variant alleles $C Y P 1 B 1 * 2$ and $C Y P 1 B 1 * 3$ who either smoked or chewed tobacco or drank alcohol. Another recent study (98) has also underlined the relevance of the CYPIBI genotypes combined with exposure to tobacco smoke for HNSCC susceptibility. It investigated individual genetic predisposition to HNSCC associated with enzymes of xenobiotic metabolism and repair enzymes affected by tobacco smoke and included 22 sequence variations in CYP1A1, CYP1B1, CYP2E1, ERCC2/ XPD, GSTM1, GSTP1, GSTT1, NAT2, NQO1, and $X R C C 1$. To assess relevant main and interactive effects of polymorphic genes on the susceptibility to HNSCC they used statistical models such as log regression and a Bayesian version of log regression. In subgroup analysis of nonsmokers, the main effects in ERCC2 (Lys $751 \mathrm{Gln}$ ) C/C genotype and combined ERCC2 (Arg156Arg) $C / A$ and $A / A$ genotypes were predominant. When stratifying for smokers, the data revealed main effects on $C Y P 1 B 1 * 3 / * 3$ genotypes, followed by $C Y P 1 B 1 * 1 / * 3$, and $C Y P 2 E 1 * 7 B$. When fitting log regression models including relevant main effects and interactions in smokers, the authors found relevant association beetween genotypes containing $C Y P 1 B 1 * 3$ or $C Y P 2 E 1 * 7 B$ and HNSCC as well as between $C Y P 1 B 1 * 3 / * 3$ or GSTM1 null/null genotype and HNSCC.

Another group (99) have similar approach to determine genetic interactions in HNSCC. They used log regression, which is well suited for SNPS, and Bayesian generalisation, which allows for incorporating additional expert knowledge. These methods determined several important interactions such as association between $C Y P 1 B 1$, tobacco smoke, and $p 53$ mutations and interactions between CYP1B1 and glutathione S-transferases in smokers, which included a three-way interaction between
CYP1B1, CYP2E1, and GSTP1. An association study (100) based on 1,023 patients and 1,121 controls, investigated the influence of environmental factors combinated with six SNPs located in CYP1A2, $C Y P 2 E 1, C Y P 1 B 1$, and $C Y P 2 C 9$ on the risk of sporadic colorectal cancers (CRC). Whereas separate analyses of the $S N P$ s showed no effect on CRC risk, three allelic variant combinations were found to be associated with a significant increase in CRC risk in interaction with an excessive red meat consumption. One of these three predisposing combinations was also shown to interact positively with obesity. Some study results (101) suggest that genetic polymorphisms in CYP1B1 may modify the risk of prostate cancer. Another report (102) on the association between the $C Y P 1 B 1 * 3$ allele and survival in patients with prostate cancer receiving docetaxel has provided evidence that $C Y P 1 B 1 * 3$ may be an important marker for estimating docetaxel efficacy, explaining this by $C Y P 1 B 1 * 3$ genotype-dependent oestrogen metabolism.

It appears that CYP1B1 along with Phase II enzymes play a key role in the activation of carcinogens at several organ targets, with a complex gene-environment interactions.

\section{CYP2C9}

CYP2C9 is predominantly expressed in the liver, representing about $20 \%$ of the hepatic CYP content. It metabolises about $15 \%$ of drugs in current use, some of which are of substantial clinical importance such as angiotensin-2 antagonists, nonsteroidal antiinflammatory drugs (NSAIDs), oral antidiabetics, antiepileptics, oral anticoagulants, psychotropic drugs, and alkylating anticancer prodrugs (Table 4) (103, 104). In addition, CYP2C9 metabolises endogenous substrates arachidonic and linolenic acid (105). CYP2C9 also mediates 3-hydroxylation of $\mathrm{B}[\mathrm{a}] \mathrm{P}$ and metabolic activation of several PAH-diols to active metabolites at much slower rates than those by CYP1 enzymes (106). Genetic polymorphisms of $C Y P 2 C 9$ include more than 34 alleles (41). Alleles $C Y P 2 C$ $* 2, * 3, * 4, * 5$, and $* 30$ have aminoacid replacement, and have been reported to reduce in vitro $(107,108)$ and/or in vivo catalityc activities $(108,109,110)$.

There is a large interindividual variation in CYP2C9 activity resulting in variations in drug response and adverse effects. In Caucasian population, poor metabolisers make $3 \%$ to $5 \%$. The most frequent variants are the $C Y P 2 C 9 * 2$ and $C Y P 2 C 9 * 3$ alleles. Of special interest are drug substrates with a narrow 
therapeutic index such as S-warfarin, tolbutamide and phenytoin, where impaired CYP2C9 metabolic activity might cause difficulties in dose adjustment as well as toxicity $(111,112)$. Patients with the $C Y P 2 C 9 * 2$ and $C Y P 2 C 9 * 3$ alleles have lower mean daily warfarin doses and a greater risk of bleeding (113). CYP2C9 polymorphisms can also be associated with an increased rate of NSAID-induced adverse events (114). NSAIDs have been shown to effectively prevent colorectal neoplasia. Polymorphisms in NSAID targets or metabolising enzymes may affect NSAID efficacy or toxicity (115). Some authors (116) reported enhanced chemopreventive activity of ibuprofen against colorectal cancer by slowermetabolising CYP2C9 variants $(* 2 / * 3)$. Others (117) investigated the association of elimination rate and clinical outcome of anticancer agent indisulam with $C Y P 2 C 9 / C Y P 2 C 19$ gene variants. $C Y P 2 C 9 * 3$, $C Y P 2 C 19 * 2$, and $C Y P 2 C 19 * 3$ polymorphisms resulted in a reduced elimination rate of indisulam. These mutant alleles significantly increase the risk of severe neutropenia, and dose reductions of $50 \mathrm{mg} \mathrm{m}^{-2}$ to $100 \mathrm{mg} \mathrm{m}^{-2}$ per mutated allele may be required to normalise the risk.

Beside genetic polymorphisms, interindividual variability in CYP2C9 enzyme activity can also be changed by environmental factors; it is induced by prototypical CAR, PXR, and GR ligands through different elements in the promoter region or inhibited by oral contraceptives, as shown in a study on healthy women (118). The observed intraethnic variability reinforces the need for proper selection of control subjects and argues against the use of surrogate control groups for studies on the association between CYP2C9 alleles and adverse drug reactions or spontaneous diseases (119).

\section{CYP2C19}

When it comes to drug metabolysm catalysed by CYP2C19, two to five percent of Caucasians and about $20 \%$ of Asians are poor metabolisers (PMs) (120). Currently, there are over 25 different alleles of the CYP 2 C19 gene $(2 C 19 * 1-* 25)$, of which CYP $2 C 19 * 2$ $* 8$ code for inactive versions of the enzyme and CYP 2 C19*17 for increased enzyme activity (41). In Asians, alleles CYP2C19*2 and *3 together account for $100 \%$ of the defective alleles. In the Caucasian population $85 \%$ of PMs are homozygous for CYP 2 C19*2. CYP2C19*3 to $* 25$ alleles are extremely rare in Caucasians. The CYP2C19 genotype can seriously affect the success of drug therapy. In PMs, proton pump inhibitor omeprazole has a considerably prolonged half-life. Patients heterozygous for a defective CYP2C19 allele displayed an improved cure rate for Helicobacter pylori infections during concomitant omeprazole and amoxicillin treatment. Patients with two defective alleles had a cure rate of $100 \%$ (121). Other important clinically used drugs that are affected by CYP2C19 polymorphisms are the tricyclic antidepressants amitriptyline and clomipramine, selective serotonin reuptake inhibitors sertraline and citalopram, the monoamine oxidase inhibitor moclobemide, barbiturates, the anxiolytic diazepam and the antimalarial drug proguanil (Table 5) (122). The CYP2C19 phenotype is measured through oral administration of S-mephenytoin. In individuals with the extensive metabolic phenotype, S-mephenytoin is quickly conjugated and excreted in the urine. In contrast, in PMs, virtually no hydroxylation occurs. A recent study found that patients ( $\mathrm{n}=166$ ) on escitalopram therapy, carrying the CYP 2 C19*17 allele (UM phenotype) exhibited $42 \%$ lower plasma concentrations than those homozygous for $C Y P 2 C 19^{*} 1$ and underlined the necessity of dose adjustment (123). The rate of nelfinavir (for HIV treatment) biotransformation to M8 was reduced by $50 \%$ in patients with the CYP $2 C 19 * 1 / * 2$ or $* 2 / * 2$ genotype compared to those with the $* 1 / * 1$ genotype, with consequences of modified short-term efficacy and toxicity and final virological response (124). Some reports documented that the CYP $2 C 19 * 2$ loss-of-function polymorphism was associated with an increased treatment-related mortality (TRM) in patients undergoing allogenic transplantation (125). Patients genotyped as PMs had a significantly higher rate of hepato- and nephrotoxicities than intermediate or extensive metabolisers. Multivariate analysis including all potential factors that might influence TRM have confirmed that the CYP2C19 genotype is an independent factor which considerably influences TRM. These results suggest that genotyping for CYP2C19 can help to identify patients with a higher risk of TRM.

\section{CYP2D6}

CYP2D6 constitutes a surprisingly important enzyme for drug metabolism, despite its low hepatic content (about $2 \%$ ). Its polymorphisms are of the greatest importance for drug metabolism of all phase I and II metabolising enzymes. There are more than 80 different allelic variants, and about $25 \%$ of all drugs on the market are metabolised by this enzyme (126). 
The most important substrates of CYP2D6 (Table 6) are antidepressants, neuroleptics, antiarrhytmics, analgesics, antiemetics, and anticancer drugs (127, 128). The enzyme also appears to be one of the most important polymorphic drug metabolizing enzymes in causing adverse drug reactions (129). In addition, the enzyme utilises amines and steroids as endogenous substrates (5-methoxyindolethylamine and 5methoxytryptamine) (130). Besides, it may have a major role in the metabolism of food constituents, alkaloids in particular (131). CYP2D6 is the only non-inducible drug metabolizing CYP, and therefore, genetic variation contributes largely to interindividual variation in enzyme activity. Different functional CYP2D6 gene variants have been described which can be classified in categories according to whether they abolish, decrease, leave normal, increase, or qualitatively alter catalytic activity. The distribution of the most common variant alleles among ethnic groups and all variant alleles are presented at the home page of the human CYP allele nomenclature committee (41). The most important variants are $C Y P 2 D 6 * 2$, $C Y P 2 D 6 * 3, C Y P 2 D 6 * 4, C Y P 2 D 6 * 5, C Y P 2 D 6 * 6$, $C Y P 2 D 6^{*} 10, C Y P 2 D 6^{*} 17$, and $C Y P 2 D 6 * 41$. There are four polymorphism-related phenotypes; poor (PM), intermediate (IM), extensive (EM), or ultrarapid metabolisers $(\mathrm{UM})$. It is plausible that the UM genotype (CYP2D $6 * 2 x N$-duplications), with more than one active gene on one allele, is the outcome of selective diet in certain North and East African populations (132). In the Ethiopian and Algerian population the prevalence of UMs is $29 \%(133-135) .20 \%$ of the population in Oceania are also UMs. However, the duplication event in the Oceania population appears to be of another origin since the allele found is $C Y P 2 D 6^{*} 1 X n$, and has most probably evolved independently from the duplication in the African population. The UM phenotype makes $1 \%$ to $10 \%$ of the European population and the PM phenotype $3 \%$ to $10 \%$ (136-139).

New variants of the CYP2D6 gene are continuously added to the CYP allele Web page (41). Genotyping for 12 SNPS representing 20 different haplotypes would predict the real phenotype with about $90 \%$ to $95 \%$ accuracy (140). Phenotyping with a probe drug like dextromethorphan might provide an even more accurate estimate (141).

CYP2D6 polymorphism significantly affects the pharmacokinetics of about $50 \%$ of drugs in clinical use (Table 6). The consequences at normal drug doses can be either adverse drug reactions $(142,143)$ or no drug response (144). CYP2D6 polymorphism can affect the efficacy and cost of drug treatment. Predictive CYP2D6 genotyping is estimated to be beneficial for treatment of about $30 \%$ to $50 \%$ of CYP2D6 drug substrates (145). The CYP2D6 genotype has been shown to successfully predict the clearance of antidepressants desipramine, fluvoxamine, mexiletine, mianserin, nortryptiline, and paroxetine as well as the clearance of the neuroleptics perphenazine and zuclopenthixol and the competitive muscarinic receptor antagonist tolterodine (146). A lack of CYP2D6 enzyme results in reduced effectiveness of drug therapy in instances where prodrugs requiring activation by CYP2D6 are used. This is seen for the analgesic effect of tramadol and codeine. Tamoxifen is metabolised into its active metabolite endoxifen by $\mathrm{N}$-demethylation and 4-hydroxylation, reactions that are catalysed by CYP2D6. Lower therapeutic effect has been observed in PMs for CYP2D6, and predictive pheno/genotyping is advised before entering the treatment (147). When a prodrug like codeine is administered to UMs they may suffer of adverse effects due to higher-than-expected concentrations of active metabolite morphine $(148,149)$. Mutations in CYP2D6 gene can also alter substrate specificity (150).

\section{CYP2E1}

In the CYP2E locus only one gene has been described in humans. CYP2E1 is expressed in the liver with the highest concentration in the centrilobular region. This enzyme is reasonably conserved, most likely due to important endogenous roles. The endogenous regulation of CYP2E1 is similar to that of other gluconeogenetic enzymes; the enzyme expression

Table 5 Important drugs which are substrates of enzyme CYP2C19

\begin{tabular}{ll}
\hline Drug groups & Drugs \\
\hline Anticonvulsants & barbiturates, phenytoin, valproates \\
Proton pump inhibitors & omeprazole, lansoprazole, pantoprazole \\
Psychotropic drugs & diazepam, imipramine, clomipramine, sertraline, citalopram, moclobemide \\
Other & proguanil, propranolol, ritonavir, tolbutamide \\
\hline
\end{tabular}


is repressed during normal diet and increased during starvation and diabetes. Its physiological substrates seem to be gluconeogenetic precursors acetone and acetol and fatty acids. A study in rats (151) showed increased CYP2E1 either at transcriptional or posttranscriptional level in chemically induced diabetes and starvation.

The expression of CYP2E1 is also regulated by different cytokines. Similar to CYP1A2, CYP2C, and CYP3A, the level of CYP2E1 is decreased by IL-1, IL- 6 , and TNF- $\alpha$ in primary culture of human hepatocytes (152). By contrast, IL-4 induces the expression of the enzyme. CYP2E1 has a very broad substrate specificity. More than 70 different chemicals with diverse structures are metabolised by CYP2E1 (Tables 1 and 2). Most of these substrates are small and hydrophobic. They include alcohols/ketones/ aldehydes, aromatic compounds, halogenated alkanes or alkenes, anaesthetics, drugs, and premutagens such nitrosamines (found in cigarette smoke) and azo carcinogens (153-156). Many of the CYP2E1 substrates are also inducers of the enzyme. Commonly used inducers in experimental animals are ethanol, acetone, isoniazid, pyridine, and pyrazole. CYP2E1 activity in liver microsomes and in vivo is most often measured using the chlorzoxazone 6-hydroxylation method. Although the frequency of variant alleles is high, their functional significance is not clear, most likely due to a high endogenous importance of this enzyme in gluconeogenesis during severe fasting/starvation. Some investigations suggest that the CYP $2 E 1 * 5 B$ variant increases the susceptibility to colorectal cancer (157). In general, gene-environment interactions between $C Y P 2 E 1$ polymorphism and smoking or alcohol drinking have been associated with the risk of colorectal neoplasia. Vinyl chloride (VC) is a human carcinogen known to be metabolised by CYP2E1 into reactive intermediates that can cause oncogene and tumour suppressor gene mutations, and which are further metabolised by acetaldehyde dehydrogenase (ALDH2) and glutathione-S-transferases to nonmutagenic end-products. Schindler et al. (158) have found that the presence of the $C Y P 2 E 1 * 5 B$ allele variant was significantly associated with the either or both mutant biomarkers (ras- $p 21$ and $p 53$ ), even after controlling for potential confounders, including cumulative $\mathrm{VC}$ exposure. The effects of $* 5 B$ allele and $\mathrm{VC}$ exposure were approximately additive. These results also suggest possible gene-environment interactions between polymorphisms in the $\mathrm{VC}$ metabolic pathway and $\mathrm{VC}$ exposure that could contribute to variable susceptibility to the mutagenic effects of VC in exposed populations. Other data (159) also suggest that genetic polymorphism in CYP2E1 may be associated for individual differences in susceptibility to liver fibrosis with regard to chronic vinyl chloride monomer (VCM) exposure. Analysis of metabolising enzymes might be useful in the risk assessment of liver damage in workers occupationally exposed to VCM.

Some published data (160) suggest that the genotypes of $C Y P 2 E 1$ and of DNA repair genes XRCC1 194 (X-ray repair cross-complementing group ) and XPD 751 (xeroderma pigmentosum complementary group D) are associated with the level of DNA damage, and that they may contribute to variable sensitivity to DNA damage induced by VCM at the workplace. The CYP2E*5B and NAT2 variants $(N A T 2 * 4 / * 7, N A T 2 * 5 / * 6, N A T 2 * 5 / * 7, N A T 2 * 6 / * 6$ and $N A T 2 * 6 / * 7$ genotypes) were associated with chronic obstructive pulmonary disease (161). A group of Norwegian scientists (162) in their comprehensive study of 105 SNPs in 31 xenobiotic-metabolising enzyme genes found strong associations with the risk of NSCLC. Results indicated that several SNPS in phase I genes CYP1B1, CYP2D6, CYP2E1, and CYP3A4 were associated with the risk of NSCLC. Moreover, significant associations were also found

Table 6 Important drugs which are substrates of enzyme CYP2D6

\begin{tabular}{ll}
\hline Drug groups & Drugs \\
\hline Analgesics & $\begin{array}{l}\text { codeine, dextromethorphan, fentanyl, hydrocodon, meperidine, methadone, morphine, } \\
\text { oxycodone, tramadol } \\
\text { amiodarone, aimaline, flecainide, lidocaine, mexiletin, propafenone }\end{array}$ \\
Antiarrhythmics & $\begin{array}{l}\text { alprenolol, bisoprolol, bufuralol, carvedilol, labetalol, metoprolol, pindolol, propranolol, } \\
\text { timolol } \\
\text { antagonists }\end{array}$ \\
amphetamine, amitriptyline, fluoxetine, fluvoxamine, haloperidol, imipramine, \\
Psychotropic drugs & $\begin{array}{l}\text { clomipramine, chlorpromazine, clozapine, maprotiline, paroxetine, risperidone, } \\
\text { thioridazin, trazodone, venlafaxin, zuclopenthixol } \\
\text { guanoxane, captopril, tamoxifen, trimetoprim }\end{array}$ \\
\hline
\end{tabular}


with multiple $S N P$ s in phase II genes $A L D H 2, C O M T$, EPHX1, SOD2, NAT1, NAT2, GSTM3, GSTP1, GSTT2, and MPO.

\section{CYP $3 A 4 / 5$}

CYP3A4 is the most abundant P450 enzyme in the human liver (about $30 \%$ of total P450). CYP3A enzymes facilitate the metabolism of a wide range of structurally different xenobiotics and of $50 \%$ of all clinically used drugs (Table 7) $(163,164)$. In addition, they have a key role in the metabolism of endogenous substrates such as retinoic and bile acids and steroid hormones such as testosterone and oestrogen $(127,165)$. CYP3A4 is also very important for the metabolism/activation of dietary and environmental chemicals such as PAH-diols, mycotoxins, aflatoxins B1, G1, and sterigmatocystin, pesticides, flavonoids, and a number of food additives (166-168). Catalytic activity of CYP3A4 in PAH activation is lower than of the CYP1 family enzymes. There are four CYP3A human genes, CYP $3 A 4$, CYP $3 A 5$, CYP $3 A 7$, and CYP3A43, located at chromosome 7q21-q22.1 (169).

Clinically relevant CYP3A enzymes, CYP3A4, CYP3A5 and CYP3A7, have similar substrate specificities and are mostly expressed in the liver. CYP3A4 and CYP3A7 show an opposite expression pattern during development (170). CYP3A7 is predominantly expressed in the foetal liver and is present up to 6 months of postnatal age, although this enzyme can be found in some adult livers and in other organs (171). CYP3A4 is the major cytochrome P450 isoform present in adult liver. CYP3A5 content is constant at all developmental stages, regardless of polymorphism. In the foetus, CYP3A7 plays an important role in the metabolism of endogenous substrates, such as key steroids and retinoic acid, and also in the metabolism of xenobiotics reaching the foetus from maternal circulation. Interindividual variation in CYP3A7 expression could therefore result in interindividual differences in embryotoxicity and teratogenicity of different substances $(172,173)$.

CYP3A4 can be inhibited by a number of drugs and chemicals. These include azole antifungal agents such as ketoconazole, macrolide antibiotics such as troleandomycin, HIV protease inhibitors such as saquinavir, antidepressants such as fluoxetine, and furanocoumarin, 6', 7'-dihydroxybergamottin found in grapefruit juice (174-176). CYP3A4 enzyme is also highly inducible by many drugs and dietary chemicals. Drug inducers include the macrolide antibiotic rifampicin, anticonvulsants such as carbamazepine, and glucocorticoids. Components of St John's wort (Hypericum perforatum), hyperforin in particular, are potent inducers of CYP3A4 (177). All of them are importan for interactions during pharmacotherapy. Statins (antilipemic drugs) are mainly metabolised by CYP3A4, except fluvastatin, which is metabolised by CYP2C9 and pravastatin, which is largely excreted unchanged. Myopathy is a serious adverse effect of statins. Concurrent use of statins and fibrates, seems to particularly increase the risk of muscular toxicity (178).

Coadministration with rifampicin, phenytoin, or carbamazepine may reduce plasma AUCs to less than half for a broad range of CYP3A4 drug substrates (179). A combination of a powerful inhibitor of CYP3A4 and a drug dependent on CYP3A4 for its metabolism may increase plasma levels of the substrate as much as 10 to 20 times and lead to adverse drug reactions and toxic effects. Correspondingly, a combination with an inducer may decrease plasma levels of the substrate to only $5 \%$ to $10 \%$ of its original concentration, leading to therapeutic failure (180). There is large interindividual variability in hepatic CYP3A4 expression (181). CYP3A4 is also highly expressed in the intestine (182). The enzyme has a substrate specificity and inducibility that is similar to the drug transporter P-glikoprotein (P-gp) encoded by the multi-drug resistant/ATP binding cassette (MDR1/ABCB1) gene $(183,184)$. Both genes are on the same position on chromosome $7 \mathrm{q} 21.1$ and apparently use similar DR4 regulatory elements binding PXR $(185,186)$. The broad substrate specificity, the capacity of CYP3A4 to metabolise xenobiotics, and co-regulation with P-gp makes these two components perhaps the most important complex for the elimination of xenobiotics from the body (187-190). Probe substrates for CYP3A4 include midazolam (1' hydroxylation), erythromycin (N-demethylation), cortisol (6ß-hydroxylation in vivo) and testosterone ( $6 \beta$-hydroxylation in vitro). Although there is a considerable interindividual variation in the expression and activity of CYP3A4, genetic polymorphisms alone do not provide a satisfactory explaination (191). More than 20 mutations in the CYP3A4 gene have been identified, but were of unclear importance (41). Different CYP3A4 variant proteins have been described, with decreased $\left(* 8, * 11,{ }^{*} 13 * 17\right)$, none $(* 20)$, or increased activity $(* 18 A)$ allele in vitro. However, their low frequency cannot explain common interindividual differences in CYP3A4 activity. This 
suggests that the enzyme is rather well preserved as a result of selection pressure in the past to preserve its function in the metabolism of dietary and other environmental factors. Reasons for variations in CYP3A4 expression and inducibility could be in variations in genes encoding proteins participating in the regulation of CYP3A4 transcription of $P X R$, $C A R$ and $G R$ ligands and in the genes controlling posttranslational regulation of the protein (192-194).

Similar to CYP3A4, CYP3A7 is a well-conserved gene, and up to now one frameshift mutation $\left(C Y P 3 A 7^{*} 3\right)$ and one coding polymorphism have been identified $(C Y P 3 A 7 * 2)(195,196)$. CYP $3 A 7 * 2$ allele has a frequency of $8 \%, 28 \%$, and $62 \%$ in Caucasians, Asians, and Africans, respectively, but the impact of this polymorphism on foetal drug clearance and endogenous substrate metabolism is still unclear. CYP3A7-specific antibodies show that about $10 \%$ of adult livers express significant CYP3A7 protein levels that contribute to $24 \%$ of total CYP3A protein in these livers.

CYP3A5 has a wide tissue distribution, but is expressed at a much lower level than CYP3A4. Only about $20 \%$ of people express CYP3A5 in the liver. Its expression is generally higher among AfricanAmericans than Caucasians $(197,198)$. The most common reason for non-expression is a splice site mutation. The frequency of variant alleles shows interethnic differences with the wild-type $C Y P 3 A 5 * 1$ allele more common in Africans than Caucasians and Asians (199).
Variability in CYP3A5 expression is a result of several SNPs (200), which severely diminish the synthesis of functional CYP3A5 like CYP $3 A 5^{*} 3{ }^{*}$, 6 (41). Substrate specificity of CYP3A5 is similar to that of CYP3A4, but it is less active. CYP $3 A 4$ and $C Y P 3 A 5$ genes share a common regulatory pathway for constitutive expression (201). Important substrates of CYP3A5 are immunosuppressive drugs cyclosporine, tacrolimus, sirolimus, and everolimus, which show a large interindividual variability in pharmacokinetic properties and a narrow therapeutic index (202). Eight independent studies have demonstrated faster clearance of drug substrates by variants carrying one or two $C Y P 3 A 5^{*} 1$ alleles. Some published data suggest that $C Y P 3 A 4, C Y P 3 A 5$, and $C Y P 3 A 7$ polymorphisms affect cyclosporine metabolism, and therefore their genotyping could be useful to prospectively optimise cyclosporine prescription in transplant recipients (203). Recent reports also indicate that dose levels of tacrolimus need to be adjusted in transplant patients according to CYP $3 A 5$ polymorphism (204). $C Y P 3 A 5^{*} 1$ homozygotes may have higher systolic blood pressure due to hormone status (199). Some studies explored if individual variations in CYP3A may play a role in breast and prostate carcinogenesis through modulation of sex hormone metabolite levels, or through metabolic activation of exogenous carcinogens (205). Certain combined CYP3A4/ CYP $3 A 5$ haplotypes showed differential susceptibility to prostate cancer. Results obtained suggest that the interaction between $C Y P 3 A 5 * 3$ polymorphisms and

Table 7 Important drugs which are substrates of enzyme CYP3A4

\begin{tabular}{|c|c|}
\hline Drug groups & Drugs \\
\hline Analgesics & acetaminophen, alfentanil, codeine, dextromethorphan \\
\hline Antiarrhythmics & dysopiramide, lidocaine, quinidine \\
\hline Antimicrobials & $\begin{array}{l}\text { doxycycline, erytromycin, clarithromycin, clindamycin, ketoconazole, miconazole, } \\
\text { troleandomycin, HIV-protease inhibitors }\end{array}$ \\
\hline Antihistamines & astemizole, loratadine, terfenadine \\
\hline Anticonvulsant & carbamazepine, etosuximide \\
\hline Antilipemics & atorvastatin, fluvastatin, lovastatin, simvastatin \\
\hline Antitumour drugs & $\begin{array}{l}\text { busulphan, cyclophosphamide, doxorubicin, paclitaxel, tamoxifen, vinblastine, } \\
\text { vincristine }\end{array}$ \\
\hline Ca channel blockers & amlodipine, felodipine, nifedipine, nimodipine, verapamil \\
\hline Steroids & estradiol, cortisol, progesterone, prednisone, testosterone \\
\hline Immunosuppressants & cyclosporin, sirolimus, tacrolimus \\
\hline Cardiotonic glycoside & digitoxin \\
\hline Narcotics & methadone, cannabinoids, cocaine, fentanyl \\
\hline Psychotropic drugs & $\begin{array}{l}\text { amphetamines, fluoxetine, haloperidol, clomipramine, clonazepam, chlorpromazine, } \\
\text { midazolam, risperidone, triazolam }\end{array}$ \\
\hline
\end{tabular}


androgen metabolism pathway seems to be significant in prostate cancer (206). In a study by Plummer et al. (207) $C Y P 3 A 4 * 1 B / C Y P 3 A 5 * 3$ haplotype was positively associated with prostate cancer risk and aggressiveness.

In a multiethnic population study, $C Y P 3 A 4-G$ variant $(* 1 B)$ was more common among AfricanAmericans than among white men. Race-stratified analyses revealed little association between the CYP $3 A 4$ variant and prostate cancer risk among white men, but were limited by the small number of white men with the $C Y P 3 A 4 * 1 B$ variant. However, $* 1 B / * 1 B$ genotype was significantly associated with aggressive prostate cancer in African-American men (208). Females carriers of $C Y P 3 A 5^{*} 1$ (high activity enzyme) appear to reach puberty earlier, which may affect breast cancer risk. Postmortem and in vivo studies have provided the first scientific evidence that CYP3A5 is involved in fentanyl metabolism, and homozygous CYP $3 A 5^{*} 3$ causes impaired metabolism of fentanyl. The authors have suggested that genotyping for $C Y P 3 A 4 * 1 B$ and $3 A 5 * 3$ variants may help to confirm fentanyl toxicity (209).

\section{CONCLUSION}

In everyday life, human body is exposed to a number of xenobiotics including drugs, dietary compounds, or environmental carcinogens, which are metabolised by a variety of enzymes through phase I and phase II reactions. These enzymes mainly participate in the conversion of xenobiotics to more polar and watersoluble metabolites which are readily excreted from the body. During metabolism of certain xenobiotics, a variety of unstable and reactive intermediates can be formed, which attack DNA, causing cell toxicity and transformation. Individuals differ in the levels of expression and catalytic activities of metabolic enzymes that activate and/or detoxify xenobiotics in various organs, and these phenomena are thought to be critical in understanding the background of interindividual differences in response to xenobiotics. Factors affecting these variations include induction and inhibition of enzymes by diverse chemicals and by genetic polymorphisms. Inherited DNA sequence variations in genes coding for metabolic enzymes may have major effects on the efficacy/toxicity and carcinogenic potency of xenobiotics. New methods in molecular biology and improved genotyping procedures have become available and have been applied extensively in association studies between metabolic enzyme gene variants and cancer risk. For some CYPs (primarily CYP1A1, CYP1A2, CYP1B1, and CYP2E1) consistent evidence has been reported for the association between polymorphisms and cancer susceptibility. The pathways of carcinogen metabolism are complex, mediated by the activities of multiple genes, as single genes may have a limited impact on cancer risk. The knowledge of environmental determinants and large studies with detailed exposure information are crucial to evaluate reliably any moderate genetic effects. Many controversial data are present in literature. Positive associations were found in certain populations and not confirmed in others. In addition to an expected interethnic variability in allele frequencies, variability has also been found within an ethnic group, resulting in heterogeneity in association studies. Gene-environment interactions could be a confounding factor in these studies, with controversial findings on cancer risk. Furthermore, gene-environment interaction assessment requires a large number of samples in order to achieve significance. Detection of small genetic effects also requires a very large and homogenous sample. Small sample size has limitations, particularly after stratification with respect to risk factors. Due to small samples, estimates may be imprecise, erratic, and biased. Therefore certain findings should be taken with caution. Replication studies are warranted for further conclusions, with careful characterisation of the most confounding factors such as diet, including alcohol and coffee consumption, smoking or tobacco chewing, age, sex, hormonal status, lifestyle, and related diseases. Technological advances in molecular biology which enable genotyping of a large number of SNPs (DNA microarray) and reliable information regarding toxic/ carcinogenic exposure could contribute to obtain more conclusive findings in further studies.

Genetic variability of CYP2C9, CYP2C19, and CYP2D6 is clinically the most important of all CYPs. Predicting therapeutic failure or severe adverse drug reactions by genotyping for important polymorphisms in key drug-metabolising enzymes has a potential to optimize drug choice and/or dose at the beginning of therapy, avoiding most adverse effects, and decreasing medical costs. Among the particularly important treatment regimens affected by genetic polymorphisms of CYPs are therapies with drugs with a narrow therapeutic index such as some antidepressants, anticoagulants, anticonvulsants, antidiabetics, antipsychotics, and anticancer drugs. In 
2007, the United States Food and Drug Administration (FDA) announced for the first time that warfarin's (anticoagulant) label would carry new information describing the role of genetics in drug dosing. The label states that a lower initial warfarin dose "should be considered for patients with certain genetic variations" (210). Genotyping of CYP2C9 and vitamin $\mathrm{K}$-epoxid reductase complex $\mathrm{C} 1$ (VKORC1), which is warfarins' target, is recommended before dosing. The FDA also approved the microarray-based AmpliChip CYP450 test, which analyzes genotypes for CYP2D6 and CYP2C19, and is another step toward predicting the safety and efficacy of a drug in individual patients (211). The FDA has been proactive in a number of other ways, including the publication of the "Pharmacogenomics Guidance Document" (212).

While pharmacogenomics is a promising approach to reduce ADRs and increase therapeutic efficacy, the clinical relevance of genetic variability for drug action and metabolism remains to be assessed in many cases. It is generally believed that clinicians tend to ignore a large amount of new information pertaining to pharmacogenetic testing. The main steps for successful implementation of pharmacogenetic testing should include education of clinicians and all others involved in the use and benefits of testing, large prospective association studies showing the benefits of pharmacogenomic genotyping, development of specific clinical guidelines, and creation of a regulatory and ethical framework for testing.

\section{REFERENCES}

1. Meyer U. Molecular mechanisms of genetic polymorphisms of drug metabolism. Annu Rev Pharmacol Toxicol 1997;37:269-96.

2. Linder MW, Prough RA, Valdes R. Pharmacogenetics: a laboratory tool for optimizing therapeutic efficiency. Clin Chem 1997:43:254-66.

3. Weinshilboum R. Inheritance and drug response. N Engl J Med 2003;348:529-37.

4. Evans WE, Relling MV. Moving towards individualized medicine with pharmacogenomics. Nature 2004;429:464-8.

5. McLeod HL, Evans WE. Pharmacogenomics: unlocking the human genome for better drug therapy. Annu Rev Pharmacol Toxicol 2001;41:101-21.

6. Omenn GS. Prospects for pharmacogenetics and ecogenetics in the new millennium. Drug Metab Dispos 2001;29:611-4.

7. Reszka E, Wasowicz W, Gromadzinska J. Genetic polymorphism of xenobiotic metabolising enzymes, diet and cancer susceptibility. Br J Nutr 2006;96:609-19.

8. Schmidt CW. Toxicogenomics - An emergin discipline Eniron Health Perspect 2002;110:A750-5.

9. Ingelman-Sundberg M. Human drug metabolising cytochrome P450 enzymes: properties and polymorphisms.
Naunyn-Schmiedeberg's Arch Pharmacol 2004;369:89104.

10. Maglich JM, Stoltz CM, Goodwin B, Hawkins-Brown D, Moore JT, Kliewer SA. Nuclear pregnane x receptor and constitutive androstane receptor regulate overlapping but distinct sets of genes involved in xenobiotic detoxification. Mol Pharmacol 2002;62:638-46.

11. Xu C, Li CY, Kong AN. Induction of phase I, II and III drug metabolism/transport by xenobiotics. Arch Pharm Res 2005;28:249-68.

12. Belitsky GA, Yakubovskaya MG. Genetic polymorphism and variability of chemical carcinogenesis. Biochemistry (Moscow) 2008;73:543-54.

13. Shimada T, Hayes CL, Yamazaki H, Amin S, Hecht SS, Guengerich FP, Sutter TR. Activation of chemically diverse procarcinogens by human cytochrome P-450 1B1. Cancer Res 1996;56:2979-84.

14. Rodriguez-Antona C, Ingelman-Sundberg M. Cytochrome P450 pharmacogenetics and cancer. Oncogene 2006;25:167991.

15. Autrup H. Genetic polymorphisms in human xenobiotica metabolizing enzymes as susceptibility factors in toxic response. Mutat Res 2000;464:65-76.

16. Zhou M, Maitra SR, Wang P. The potential role of transcription factor aryl hydrocarbon receptor in downregulation of hepatic cytochrome P-450 during sepsis. Int J Mol Med 2008;21:423-

17. Yang X, Solomon S, Fraser LR, Trombino AF, Liu D, Sonenshein GE, Hestermann EV, Sherr DH. Constitutive regulation of CYP1B1 by the aryl hydrocarbon receptor $(\mathrm{AhR})$ in pre-malignant and malignant mammary tissue. $\mathrm{J}$ Cell Biochem 2008;104:402-17.

18. Oinonen T Lindros KO. Zonation of hepatic cytochrome P450 expression and regulation. Biochem J 1998;329:17-35.

19. Lamba JK. Pharmacogenetics of the constitutive androstane receptor. Pharmacogenomics 2008;9:71-83.

20. Chen D, Tian T, Wang H, Liu H, Hu Z, Wang Y, Liu Y, Ma H, Fan W, Miao R, Sun W, Wang Y, Qian J, Jin L, Wei Q, Shen H, Huang W, Lu D. Association of human aryl hydrocarbon receptor gene polymorphisms with risk of lung cancer among cigarette smokers in a Chinese population. Pharmacogenet Genomics 2009;19:25-34.

21. Houston JB, Galetin A. Methods for predicting in vivo pharmacokinetics using data from in vitro assays. Curr Drug Metab 2008;9:940-51.

22. Hyland R, Dickins M, Collins C, Jones H, Jones B. Maraviroc: in vitro assessment of drug-drug interaction potential. $\mathrm{Br} \mathrm{J}$ Clin Pharmacol 2008;66:498-507.

23. Youdim KA, Zayed A, Dickins M, Phipps A, Griffiths M, Darekar A, Hyland R, Fahmi O, Hurst S, Plowchalk DR, Cook J, Guo F, Obach RS. Application of CYP3A4 in vitro data to predict clinical drug-drug interactions; predictions of compounds as objects of interaction. Br J Clin Pharmacol 2008;65:680-92.

24. Diaz DS, Kozar MP, Smith KS, Asher CO, Sousa JC, Schiehser GA, Jacobus DP, Milhous WK, Skillman DR, Shearer TW. Role of specific cytochrome P450 isoforms in the conversion of phenoxypropoxybiguanide analogs in human liver microsomes to potent antimalarial dihydrotriazines. Drug Metab Dispos 2008;36:380-5.

25. Lobo ED, Bergstrom RF, Reddy S, Quinlan T, Chappell J, Hong Q, Ring B, Knadler MP. In vitro and in vivo evaluations 
of cytochrome P450 1A2 interactions with duloxetine. Clin Pharmacokinet 2008;47:191-202.

26. Andersson TB, Sjoberg H, Hoffmann KJ, Boobis AR, Watts P, Edwards RJ, Lake BG, Price RJ, Renwick AB, Gomez-Lechon MJ, Castell JV, Ingelman-Sundberg M, Hidestrand M, Goldfarb PS, Lewis DF, Corcos L, Guillouzo A, Taavitsainen P, Pelkonen O. An assesment of human liverderived in vitro systems to predict the in vivo metabolism and clearance of almokalant. Drug Metab Dispos 2001;7:1220.

27. Ulbricht $\mathrm{C}$, Chao W, Costa D, Rusie-Seamon E, Weissner W, Woods J. Clinical evidence of herb-drug interactions: a systematic review by the natural standard research collaboration. Curr Drug Metab 2008;9:1062-119.

28. Pal D, Mitra AK. MDR- and CYP3A4-mediated drug-herbal interactions. Life Sci 2006;78:2131-45.

29. Pittler MH, Ernst E. Systematic review: hepatotoxic events associated with herbal medicinal products. Aliment Pharmacol Ther 2003;18:451-71.

30. Nebert DW, Ingelman-Sundberg M, Daly AK. Genetic epidemiology of environmental toxicity and cancer susceptibility: human allelic polymorphisms in drugmetabolizing enzyme genes, their functional importance, and nomenclature issues. Drug Metabol Rev 1999;31:467-87.

31. Nelson D. Cytochrome P450 Homepage. http://drnelson. utmem.edu/CytochromeP450.

32. Bosch TM, Meijerman I, Beijnen JH, Schellens JH.Genetic polymorphisms of drug-metabolising enzymes and drug transporters in the chemotherapeutic treatment of cancer. Clin Pharmacokinet 2006;45:253-85.

33. Petsalo A, Turpeinen M, Pelkonen O, Tolonen A. Analysis of nine drugs and their cytochrome $\mathrm{P} 450$-specific probe metabolites from urine by liquid chromatography-tandem mass spectrometry utilizing sub $2 \mu \mathrm{m}$ particle size column. J Chromatogr A 2008;1215:107-15.

34. de Leon J, Susce MT, Johnson M, Hardin M, Maw L, Shao A, Allen AC, Chiafari FA, Hillman G, Nikoloff DM. DNA Microarray Technology in the Clinical Environment: The AmpliChip CYP450 Test for CYP2D6 and CYP2C19 Genotyping. CNS Spectr 2009;14:19-34.

35. Lazarou J, Pomeranz BH, Corey PN. Incidence of adverse drug reactions in hospitalized patients: a meta-analysis of prospective studies. JAMA 1998;279:1200-5.

36. Ingelman-Sundberg M. Pharmacogenetics: an opportunity for a safer and more efficient pharmacotherapy. J Intern Med 2001;250:186-200

37. Phillips KA, Veenstra DL, Oren E, Lee JK, Sadee W. Potential role of pharmacogenomics in reducing adverse drug reactions: a systematic review. JAMA 2001;286:2270-9.

38. Shimada T, Gillam EM, Sutter TR, Strickland PT, Guengerich FP, Yamazaki H. Oxidation of xenobiotics by recombinant human cytochrome P450 1B1. Drug Metab Dispos 1997;25:617-22.

39. Fujii-Kuriyama Y, Ema M, Mimura J, Matsushita N, Sogawa K. Polymorphic forms of the Ah receptor and induction of the CYP1A1 gene. Pharmacogenetics 1995;5:149-53.

40. Nebert DW, McKinnon RA, Puga A. Human drugmetabolizing enzyme polymorphisms: effects on risk of toxicity and cancer. DNA Cell Biol 1996;15:273-80.

41. Ingelman-Sundberg M, Daly AK, Nebert DW. Home Page of the Human Cytochrome P450 (CYP) Allele Nomenclature Committee. http://www.cypalleles.ki.se/
42. Inoue K, Asao T, Shimada T. Ethnic-related differences in the frequency distribution of genetic polymorphisms in the CYP1A1 and CYP1B1 genes in Japanese and Caucasian populations. Xenobiotica 2000;30:285-95.

43. Zhu K, Hunter S, Payne-Wilks K, Sutcliffe C, Bentley C, Roland CL, Williams SM. Potential differences in breast cancer risk factors based on CYP1A1 MspI and AfricanAmerican-specific genotypes. Ethn Dis 2006;16:207-15.

44. Taioli E, Crofts F, Trachman J, Demopoulos R, Toniolo P, Garte SJ. A specific African-American CYP1A1 polymorphism is associated with adenocarcinoma of the lung. Cancer Res 1995;55:472-3.

45. Kiyohara C, Yoshimasu K, Shirakawa T, Hopkin JM. Genetic polymorphisms and environmental risk of lung cancer: a review. Rev Environ Health 2004;19:15-38.

46. Little J, Sharp L, Masson LF, Brockton NT, Cotton SC, Haites NE, Cassidy J. Colorectal cancer and genetic polymorphisms of CYP1A1, GSTM1 and GSTT1: a case-control study in the Grampian region of Scotland. Int J Cancer 2006;119:215564.

47. Nakachi K, Imai K, Hayashi S-I, Kawajiri K. Polymorphism of the CYP1A1 and glutathione S-transferase genes associated with susceptibility to lung cancer in relation to cigarette dose in a Japanese population. Cancer Res 1993;53:2994-9.

48. Kihara M, Kihara M, Noda K. Risk of smoking for squamos and small cell carcinomas of the lung modulated by combinations of CYP1A1 and GSTM1 gene polymorphisms in a Japanese population. Carcinogenesis 1995;16:2331-6.

49. Moretti M, Dell'Omo M, Villarini M, Pastorelli R, Muzi G, Airoldi L, Pasquini R. Primary DNA damage and genetic polymorphisms for CYP1A1, EPHX and GSTM1 in workers at a graphite electrode manufacturing plant. BMC Public Health 2007;7:270.

50. Shah PP, Singh AP, Singh M, Mathur N, Pant MC, Mishra BN, Parmar D. Interaction of cytochrome P4501A1 genotypes with other risk factors and susceptibility to lung cancer. Mutat Res 2008;639:1-10.

51. Vineis $P$, Anttila S, Benhamou S, Spinola M, Hirvonen A, Kiyohara C, Garte SJ, Puntoni R, Rannug A, Strange $\mathrm{RC}$, Taioli E. Evidence of gene-gene interactions in lung carcinogenesis in a large pooled analysis. Carcinogenesis 2007;28:1902-5.

52. Cote ML, Wenzlaff AS, Bock CH, Land SJ, Santer SK, Schwartz DR, Schwartz AG. Combinations of cytochrome P-450 genotypes and risk of early-onset lung cancer in Caucasians and African Americans: a population-based study. Lung Cancer 2007;55:255-62.

53. Cote ML, Yoo W, Wenzlaff AS, Prysak GM, Santer S, Claeys GB, Vandyke AL, Land SJ, Schwartz AG. Tobacco and estrogen metabolic polymorphisms and risk of non-small cell lung cancer in women. Carcinogenesis 2009;30:626-35.

54. Shi X, Zhou S, Wang Z, Zhou Z, Wang Z. CYP1A1 and GSTM1 polymorphisms and lung cancer risk in Chinese populations: a meta-analysis. Lung Cancer 2008;59:155-63.

55. Kumar M, Agarwal SK, Goel SK. Lung cancer risk in north Indian population: role of genetic polymorphisms and smoking. Mol Cell Biochem 2009;322:73-9.

56. Yoon KA, Kim JH, Gil HJ, Hwang H, Hwangbo B, Lee JS. CYP1B1, CYP1A1, MPO, and GSTP1 polymorphisms and lung cancer risk in never-smoking Korean women. Lung Cancer 2008;60:40-6. 
57. Miyoshi Y, Takahashi Y, Egawa C, Noguchi S. Breast cancer risk associated with CYP1A1 genetic polymorphisms in Japanese women. Breast J 2002;8:209-15.

58. Miyoshi Y, Ando A, Hasegawa S, Ishitobi M, Yamamura J, Irahara N, Tanji Y, Taguchi T, Tamaki Y, Noguchi S. Association of genetic polymorphisms in CYP19 and CYP1A1 with the oestrogen receptor-positive breast cancer risk. Eur J Cancer 2003;39:2531-7.

59. Li Y, Millikan RC, Bell DA, Cui L, Tse Ch-KJ, Newman B, Conway K. Polychlorinated biphenyls, cytochrome P450 1A1 (CYP1A1) polymorphisms, and breast cancer risk among African American women and white women in North Carolina: a population-based case-control study. Breast Cancer Res 2005;7:12-8.

60. Gulyaeva LF, Mikhailova ON, PustyInyak VO, Kim IV 4th, Gerasimov AV, Krasilnikov SE, Filipenko ML, Pechkovsky EV. Comparative analysis of SNP in estrogen-metabolizing enzymes for ovarian, endometrial, and breast cancers in Novosibirsk, Russia. Adv Exp Med Biol 2008;617:359-66.

61. Hirata H, Hinoda Y, Okayama N, Suehiro Y, Kawamoto K, Kikuno N, Rabban JT, Chen LM, Dahiya R. CYP1A1, SULT1A1, and SULT1E1 polymorphisms are risk factors for endometrial cancer susceptibility. Cancer 2008;112:196473.

62. Li R, Shugart YY, Zhou W, An Y, Yang Y, Zhou Y, Zhang B, Lu D, Wang H, Qian J, Jin L. Common genetic variations of the cytochrome P450 1A1 gene and risk of hepatocellular carcinoma in a Chinese population. Eur J Cancer 2009;45:1239-47.

63. Yuan X, Zhou G, Zhai Y, Xie W, Cui Y, Cao J, Zhi L, Zhang H, Yang H, Zhang X, Qiu W, Peng Y, Zhang X, Yu $\mathrm{L}, \mathrm{Xia} \mathrm{X}, \mathrm{He}$ F. Lack of association between the functional polymorphisms in the estrogen-metabolizing genes and risk for hepatocellular carcinoma. Cancer Epidemiol Biomarkers Prev 2008;17:3621-7.

64. Park SK, Andreotti G, Sakoda LC, Gao YT, Rashid A, Chen J, Chen BE, Rosenberg PS,Shen MC, Wang BS, Han TQ, Zhang BH, Yeager M, Chanock S, Hsing AW. Variants in Hormone-Related Genes and the Risk of Biliary Tract Cancers and Stones: A Population-based Study in China. Carcinogenesis 2009;30:606-14.

65. Pereira Serafim PV, Cotrim Guerreiro da Silva ID, Manoukias Forones N. Relationship between genetic polymorphism of CYP1A1 at codon 462 (Ile462Val) in colorectal cancer. Int J Biol Markers 2008;23:18-23.

66. Goode EL, Potter JD, Bamlet WR, Rider DN, Bigler J. Inherited variation in carcinogen-metabolizing enzymes and risk of colorectal polyps. Carcinogenesis 2007;28:328-41.

67. Hou L, Chatterjee N, Huang WY, Baccarelli A, Yadavalli S, Yeager M, Bresalier RS, Chanock SJ, Caporaso NE, Ji BT, Weissfeld JL, Hayes RB. CYP1A1 Val462 and NQO1 Ser187 polymorphisms, cigarette use, and risk for colorectal adenoma. Carcinogenesis 2005;26:1122-8.

68. Nagata K, Yamazoe Y. Genetic polymorphism of human cytochrome p450 involved in drug metabolism. Drug Metab Pharmacokinet 2002;17:167-89.

69. Allorge D, Chevalier D, Lo-Guidice JM, Cauffiez C, Suard F, Baumann P, Eap CB, Broly F. Identification of a novel splicesite mutation in the CYP1A2 gene. Br J Clin Pharmacol 2003;56:341-4.

70. Murayama N, Soyama A, Saito Y, Nakajima Y, Komamura K, Ueno K, Kamakura S, Kitakaze M, Kimura H, Goto Y, Saitoh O, Katoh M, Ohnuma T, Kawai M, Sugai K, Ohtsuki
T, Suzuki C, Minami N, Ozawa S, Sawada J. Six novel nonsynonymous CYP1A2 gene polymorphisms: catalytic activities of the naturally occurring variant enzymes. J Pharmacol Exp Ther 2004;308:300-6.

71. Eap CB, Bender S, Jaquenoud Sirot E, Cucchia G, JonzierPerey M, Baumann P, Allorge D, Broly F. Nonresponse to clozapine and ultrarapid CYP1A2 activity: clinical data and analysis of CYP1A2 gene. J Clin Psychopharmacol 2004;24:214-9.

72. Bondolfi G, Morel F, Crettol S, Rachid F, Baumann P, Eap CB. Increased clozapine plasma concentrations and side effects induced by smoking cessation in 2 CYP1A2 genotyped patients. Ther Drug Monit 2005;27:539-43.

73. Bohanec Grabar P, Rozman B, Tomsic M, Suput D, Logar D, Dolzan V. Genetic polymorphism of CYP1A2 and the toxicity of leflunomide treatment in rheumatoid arthritis patients. Eur J Clin Pharmacol 2008;64:871-6.

74. Saebø M, Skjelbred CF, Brekke Li K, Bowitz Lothe IM, Hagen PC, Johnsen E, Tveit KM, Kure EH. CYP1A2 164 A$\rightarrow$ C polymorphism, cigarette smoking, consumption of welldone red meat and risk of developing colorectal adenomas and carcinomas. Anticancer Res 2008;28:2289-5.

75. Moonen H, Engels L, Kleinjans J, Kok T. The CYP1A2$164 \mathrm{~A}-->\mathrm{C}$ polymorphism $(\mathrm{CYP} 1 \mathrm{~A} 2 * 1 \mathrm{~F})$ is associated with the risk for colorectal adenomas in humans. Cancer Lett 2005;229:25-31.

76. Suzuki H, Morris JS, Li Y, Doll MA, Hein DW, Liu J, Jiao L, Hassan MM, Day RS, Bondy ML, Abbruzzese JL, Li D. Interaction of the cytochrome P4501A2, SULT1A1 and NAT gene polymorphisms with smoking and dietary mutagen intake in modification of the risk of pancreatic cancer. Carcinogenesis 2008;29:1184-91.

77. Li D, Jiao L, Li Y, Doll MA, Hein DW, Bondy ML, Evans DB, Wolff RA, Lenzi R, Pisters PW, Abbruzzese JL, Hassan MM. Polymorphisms of cytochrome P4501A2 and $\mathrm{N}$-acetyltransferase genes, smoking, and risk of pancreatic cancer. Carcinogenesis 2006;27:103-11.

78. Pavanello S, B'chir F, Pulliero A, Saguem S, Ben Fraj R, El Aziz Hayouni A, Clonfero E, Mastrangelo G. Interaction between CYP1A2-T2467DELT polymorphism and smoking in adenocarcinoma and squamous cell carcinoma of the lung. Lung Cancer 2007;57:266-72.

79. Sachse C, Brockmoller J, Bauer S, Roots I. Functional significance of a $\mathrm{C} \rightarrow \mathrm{A}$ polymorphism in intron 1 of the cytochrome P450 CYP1A2 gene tested with caffeine. Br J Clin Pharmacol 1999;47:445-9.

80. Han XM, Ou-Yang DS, Lu PX, Jiang CH, Shu Y, Chen XP, Tan ZR, Zhou HH. Plasma caffeine metabolite ratio (17X/137X) in vivo associated with G-2964A and C734A polymorphisms of human CYP1A2. Pharmacogenetics 2001;11:429-35.

81. Castorena-Torres F, Mendoza-Cantú A, de León MB, Cisneros B, Zapata-Pérez O, López-Carrillo L, Salinas JE, Albores A. CYP1A2 phenotype and genotype in a population from the Carboniferous Region of Coahuila, Mexico. Toxicol Lett 2005;156:331-9.

82. Nkondjock A, Ghadirian P, Kotsopoulos J, Lubinski J, Lynch H, Kim-Sing C, Horsman D, Rosen B, Isaacs C, Weber B, Foulkes W, Ainsworth P, Tung N, Eisen A, Friedman E, Eng C, Sun P, Narod SA. Coffee consumption and breast cancer risk among BRCA1 and BRCA2 mutation carriers. Int J Cancer 2006;118:103-7. 
83. Kotsopoulos J, Ghadirian P, El-Sohemy A, Lynch HT, Snyder C, Daly M, Domchek S, Randall S, Karlan B, Zhang P, Zhang S, Sun P, Narod SA. The CYP1A2 genotype modifies the association between coffee consumption and breast cancer risk among BRCA1 mutation carriers. Cancer Epidemiol Biomarkers Prev 2007;16:912-6.

84. Cornelis MC, El-Sohemy A, Kabagambe EK, Campos H. Coffee, CYP1A2 genotype, and risk of myocardial infarction. JAMA 2006;295:1135-41.

85. Shimada T, Hayes CL, Yamazaki H, Amin S, Hecht SS, Guengerich FP, Sutter TR. Activation of chemically diverse procarcinogens by human cytochrome P-450 1B1. Cancer Res 1996;56:2979-84.

86. Murray GI, Melvin WT, Greenlee WF, Burke MD. Regulation, function, and tissue-specific expression of cytochrome P450 CYP1B1. Annu Rev Pharmacol Toxicol 2001;41:297-316.

87. Hayes CL, Spink DC, Spink BC, Cao JQ, Walker NJ, SutterTR. 17 beta-estradiol hydroxylation catalyzed by human cytochrome P450 1B1. Proc Natl Acad Sci USA 1996;93:9776-81.

88. McKay JA, Melvin WT, Ah-See AK, Ewen SW, Greenlee WF, Marcus CB, Burke MD, Murray GI. Expression of cytochrome P450 CYP1B1 in breast cancer. FEBS Lett 1995;374:270-2.

89. Crespi CL, Penman BW, Steimel DT, Smith T, Yang CS, Sutter TR. Development of a human lymphoblastoid cell line constitutively expressing human CYP1B1 cDNA: substrate specificity with model substrates and promutagens. Mutagenesis 1997;12:83-9.

90. Murray GI, Taylor MC, McFadyen MC, McKay JA, Greenlee WF, Burke MD, Melvin WT. Tumor-specific expression of cytochrome P450 CYP1B1. Cancer Res 1997;57:3026-31.

91. Stoilov I, Akarsu AN, Alozie I, Child A, Barsoum-Homsy M, Turacli ME, Or M, Lewis RA, Ozdemir N, Brice G, Aktan SG, Chevrette L, Coca-Prados M, Sarfarazi M. Sequence analysis and homology modelling suggest that primary congenital glaucoma on 2 p21 results from mutations disrupting either the hinge region or the conserved core structures of cytochrome P4501B1. Am J Hum Genet 1998;62:573-84.

92. Van Emburgh BO, Hu JJ, Levine EA, Mosley LJ, Perrier ND, Freimanis RI, Allen GO, Rubin P, Sherrill GB, Shaw CS, Carey LA, Sawyer LR, Miller MS. Polymorphisms in CYP1B1, GSTM1, GSTT1 and GSTP1, and susceptibility to breast cancer. Oncol Rep 2008;19:1311-21.

93. Van Emburgh BO, Hu JJ, Levine EA, Mosley LJ, Case LD, Lin HY, Knight SN, Perrier ND, Rubin P, Sherrill GB, Shaw CS, Carey LA, Sawyer LR, Allen GO, Milikowski C, Willingham MC, Miller MS. Polymorphisms in drug metabolism genes, smoking, and p53 mutations in breast cancer. Mol Carcinogen 2008;47:88-99.

94. Justenhoven C, Pierl CB, Haas S, Fischer HP, Baisch C, Hamann U, Harth V, Pesch B, Brüning T, Vollmert C, Illig T, Dippon J, Ko YD, Brauch H. The CYP1B1_1358_GG genotype is associated with estrogen receptor-negative breast cancer. Breast Cancer Res Treat 2008;111:171-7.

95. Paracchini V, Raimondi S, Gram IT, Kang D, Kocabas NA, Kristensen VN, Li D, Parl FF, Rylander-Rudqvist T, Soucek P, Zheng W, Wedren S, Taioli E. Meta- and pooled analyses of the cytochrome P-450 1B1 Val432Leu polymorphism and breast cancer: a HuGE-GSEC review. Am J Epidemiol 2007;165:115-25.
96. Bethke L, Webb E, Sellick G, Rudd M, Penegar S, Withey L, Qureshi M, Houlston R. Polymorphisms in the cytochrome P450 genes CYP1A2, CYP1B1, CYP3A4, CYP3A5,CYP11A1, CYP17A1, CYP19A1 and colorectal cancer risk. BMC Cancer 2007;7:123.

97. Singh AP, Shah PP, Mathur N, Buters JT, Pant MC, Parmar D. Genetic polymorphisms in cytochrome P4501B1 and susceptibility to head and neck cancer. Mutat Res 2008;639:11-9.

98. Harth V, Schafer M, Abel J, Maintz L, Neuhaus T, Besuden M, Primke R, Wilkesmann A, Thier R, Vetter H, Ko YD, Bruning T, Bolt HM, Ickstadt K. Head and neck squamouscell cancer and its association with polymorphic enzymes of xenobiotic metabolism and repair. J Toxicol Environ Health A 2008;71:887-97.

99. Ickstadt K, Schäfer M, Fritsch A, Schwender H, Abel J, Bolt HM, Brüning T, Ko YD, Vetter H, Harth V. Statistical methods for detecting genetic interactions: a head and neck squamous-cell cancer study. J Toxicol Environ Health A 2008;71:803-15.

100. Küry S, Buecher B, Robiou-du-Pont S, Scoul C, Sébille V, Colman H, Le Houérou C, Le Neel T, Bourdon J, Faroux R, Ollivry J, Lafraise B, Chupin LD, Bézieau S. Combinations of cytochrome $\mathrm{P} 450$ gene polymorphisms enhancing the risk for sporadic colorectal cancer related to red meat consumption. Cancer Epidemiol Biomarkers Prev 2007;16:1460-7.

101. Beuten J, Gelfond JA, Byrne JJ, Balic I, Crandall AC, Johnson-Pais TL, Thompson IM, Price DK, Leach RJ. CYP1B1 variants are associated with prostate cancer in non-Hispanic and Hispanic Caucasians. Carcinogenesis 2008;29:1751-7.

102. Sissung TM, Danesi R, Price DK, Steinberg SM, de Wit R, Zahid M, Gaikwad N, Cavalieri E, Dahut WL, Sackett DL, Figg WD, Sparreboom A. Association of the CYP1B1*3 allele with survival in patients with prostate cancer receiving docetaxel. Mol Cancer Ther 2008;7:19-26.

103. Miners JO, Birkett DJ. Cytochrome P4502C9: an enzyme of major importance in human drug metabolism. Br J Clin Pharmacol 1998;45:525-38.

104. Goldstein JA. Clinical relevance of genetic polymorphism in the human CYP2C subfamily. Br J Clin Pharmacol 2001;52:349-55.

105. Yao HT, Chang YW, Lan SJ, Chen CT, Hsu JT, Yeh TK. The inhibitory effect of polyunsaturated fatty acids on human CYP enzymes. Life Sci 2006;79:2432-40.

106. Yun CH, Shimada T, Guengerich FP. Roles of human liver cytochrome $\mathrm{P} 4502 \mathrm{C}$ and $3 \mathrm{~A}$ enzymes in the 3-hydroxylation of benzo(a)pyrene. Cancer Res 1992;52:1868-74.

107. Yamazaki H, Inoue K, Chiba K, Ozawa N, Kawai T, Suzuki Y, Goldstein JA, Guengerich FP, Shimada T. Comparative studies on the catalytic roles of cytochrome P450 2C9 and its Cys- and Leu-variants in the oxidation of warfarin, flurbiprofen, and diclofenac by human liver microsomes. Biochem Pharmacol 1998;56:243-51.

108. Lee CR, Goldstein JA, Pieper JA. Cytochrome P450 2C9 polymorphisms: a comprehensive review of the in-vitro and human data. Pharmacogenetics 2002;12:251-63.

109. Haining RL, Hunter AP, Veronese ME, Trager WF, Rettie AE. Allelic variants of human cytochrome P450 2C9: baculovirus-mediated expression, purification, structural characterization, substrate stereoselectivity, and prochiral 
selectivity of the wild-type and I359L mutant forms. Arch Biochem Biophys 1996;333:447-58.

110. Yin T, Maekawa K, Kamide K, Saito Y, Hanada H, Miyashita K, Kokubo Y, Akaiwa Y,Otsubo R, Nagatsuka K, Otsuki T, Horio T, Takiuchi S, Kawano Y, Minematsu K, Naritomi H, Tomoike H, Sawada J, Miyata T. Genetic variations of CYP2C9 in 724 Japanese individuals and their impact on the antihypertensive effects of losartan. Hypertens Res 2008;31:1549-57.

111. Brandolese R, Scordo MG, Spina E, Gusella M, Padrini R. Severe phenytoin intoxication in a subject homozygous for CYP2C9*3. Clin Pharmacol Ther 2001;70:391-4.

112. Sconce EA, Khan TI, Wynne AH, Avery P, Monkhouse L, King BP, Wood P, Kesteven P, Daly AK, Kamali F. The impact of CYP2C9 and VKORC1 genetic polymorphism and patient characteristics upon warfarin dose requirements: proposal for a new dosing regimen. Blood 2005;106:232933.

113. Redman AR, Zheng J, Shamsi SA, Huo J, Kelly EJ, Ho RJY, Ritchie DM, Hon YY. Variant CYP2C9 alleles and warfarin concentrations in patients receiving low-dose versus average-dose warfarin therapy. Clin Appl Thromb Haemost 2008;14:29-37.

114. Rollason V, Samer C, Piguet V, Dayer P, Desmeules J. Pharmacogenetics of analgesics: toward the individualization of prescription. Pharmacogenomics 2008;9:905-33.

115. Cross JT, Poole EM, Ulrich CM. A review of gene-drug interactions for nonsteroidal anti-inflammatory drug use in preventing colorectal neoplasia. Pharmacogenomics J 2008;8:237-47.

116. Samowitz WS, Wolff RK, Curtin K, Sweeney C, Ma KN, Andersen K, Levin TR, Slattery ML. Interactions between CYP2C9 and UGT1A6 polymorphisms and nonsteroidal anti-inflammatory drugs in colorectal cancer prevention. Clin Gastroenterol Hepatol 2006;4:894-901.

117. Zandvliet AS, Huitema AD, Copalu W, Yamada Y, Tamura T, Beijnen JH, Schellens JH. CYP2C9 and CYP2C19 polymorphic forms are related to increased indisulam exposure and higher risk of severe hematologic toxicity. Clin Cancer Res 2007;13:2970-6.

118. Sandberg M, Johansson I, Christensen M, Rane A, Eliasson E. The impact of CYP2C9 genetics and oral contraceptives on cytochrome P450 2C9 phenotype. Drug Metab Dispos 2004;32:484-9.

119. García-Martín E, Martínez C, Ladero JM, Agúndez JA. Interethnic and intraethnic variability of CYP2C8 and CYP2C9 polymorphisms in healthy individuals. Mol Diagn Ther 2006;10:29-40.

120. Goldstein JA, Ishizaki T, Chiba K, de Morais SMF, Bell D, Krahn PM, Price Evans DA. Frequencies of the defective CYP2C19 alleles responsible for the mephenytoin poor metabolizer phenotype in various Oriental, Caucasian, Saudi Arabian and American black populations. Pharmacogenetics 1997;7:59-64.

121. Klotz U, Schwab M, Treiber G. CYP2C19 polymorphism and proton pump inhibitors. Pharmacol Toxicol 2004;95:2-8.

122. Desta Z, Zhao X, Shin JG, Flockhart DA. Clinical significance of the cytochrome P450 2C19 genetic polymorphism. Clin Pharmacokinet 2002;41:913-58.

123. Rudberg I, Mohebi B, Hermann M, Refsum H, Molden E. Impact of the ultrarapid CYP2C19*17 allele on serum concentration of escitalopram in psychiatric patients. Clin Pharmacol Ther 2008;83:322-7.
124. Hirt D, Mentré F, Tran A, Rey E, Auleley S, Salmon D, Duval X, Tréluyer JM; COPHAR2- ANRS Study Group. Effect of CYP2C19 polymorphism on nelfinavir to M8 biotransformation in HIV patients. Br J Clin Pharmacol 2008;65:548-57.

125. Elmaagacli AH, Koldehoff M, Steckel NK, Trenschel R, Ottinger H, Beelen DW. Cytochrome P450 2C19 loss-offunction polymorphism is associated with an increased treatment-related mortality in patients undergoing allogeneic transplantation. Bone Marrow Transplant 2007;40:659-64.

126. Eichelbaum M, Ingelman-Sundberg M, Evans WE. Pharmacogenomics and individualized drug therapy. Annu Rev Med 2006;57:119-37.

127. Rendic S. Summary of information on human CYP enzymes: human P450 metabolism data. Drug Metab Rev 2002;34:83448.

128. Flockhart DA. Drug Interactions: Cytochrome P450 Drug Interaction Table. http://medicine.iupui.edu/flockhart/table. htm.

129. Bertilsson L, Dahl ML, Dalen P, AL-Shurbaji A. Molecular genetics of CYP2D6: clinical relevance with focus on psychotropic drugs. Br J Clin Pharmacol 2002;53:111-22.

130. Hiroi T, Imaoka S, Funae Y. Dopamine formation from tyramine by CYP2D6. Biochem Biophys Res Commun 1988;249:838-43.

131. Gurley BJ, Swain A, Hubbard MA, Williams DK, Barone G, Hartsfield F, Tong Y, Carrier DJ, Cheboyina S, Battu SK. Clinical assessment of CYP2D6-mediated herb-drug interactions in humans: effects of milk thistle, black cohosh, goldenseal, kava kava, St. John's wort, and Echinacea. Mol Nutr Food Res 2008;52:755-63.

132. Ingelman-Sundberg M. Genetic polymorphisms of cytochrome P450 2D6 (CYP2D6): clinical consequences, evolutionary aspects and functional diversity. Pharmacogenom J 2005;5:613.

133. Meyer UA. Pharmacogenetics and adverse drug reactions. Lancet 2000;356:1667-71.

134. Meyer UA, Zanger UM. Molecular mechanisms of genetic polymorphisms of drug metabolism. Annu Rev Pharmacol Toxicol 1997;37:269-96.

135. Aklillu E, Persson I, Bertilsson L, Johansson I, Rodrigues F, Ingelman-Sundberg M. Frequent distribution of ultrarapid metabolizers of debrisoquine in an ethiopian population carrying duplicated and multiduplicated functional CYP2D6 alleles. J Pharmacol Exp Ther 1996;278:441-6.

136. Marez D, Legrand M, Sabbagh N, Guidice JM, Spire C, Lafitte JJ, Meyer UA, Broly F. Polymorphism of the cytochrome P450 CYP2D6 gene in a European population: characterization of 48 mutations and 53 alleles, their frequencies and evolution. Pharmacogenetics 1997;7:193202.

137. Scordo MG, Caputi AP, D’Arrigo C, Fava G, Spina E. Allele and genotype frequencies of CYP2C9, CYP2C19 and CYP2D6 in an Italian population. Pharmacol Res 2004;50:195-200.

138. Tamminga WJ, Wemer J, Oosterhuis B, de Zeeuw RA, de Leij LF, Jonkman JH. The prevalence of CYP2D6 and CYP2C19 genotypes in a population of healthy Dutch volunteers. Eur J Clin Pharmacol 2001;57:717-22.

139. Božina N, Granić P, Lalić Z, Tramišak I, Lovrić M, StavljenićRukavina A. Genetic Polymorphisms of Cytochromes P450: CYP2C9, CYP2C19 and CYP2D6 in Croatian Population. Croat Med J 2003;44:425-8. 
140. Sistonen J, Sajantila A, Lao O, Corander J, Barbujani G, Fuselli S. CYP2D6 worldwide genetic variation shows high frequency of altered activity variants and no continental structure. Pharmacogenet Genomics 2007;17:93-101.

141. Frank D, Jaehde U, Fuhr U. Evaluation of probe drugs and pharmacokinetic metrics for CYP2D6 phenotyping. Eur J Clin Pharmacol 2007;63:321-33.

142. Božina N, Tramišak I, Medved V, Mihaljević-Peleš A, Granić P, Stavljenić-Rukavina A. CYP2D6 genotype and psychotropic drug-induced adverse effects. Period biol 2001;103:309-14.

143. Wuttke H, Rau T, Heide R, Bergmann K, Böhm M, Weil $\mathrm{J}$, Werner D, Eschenhagen T. Increased frequency of cytochrome P450 2D6 poor metabolizers among patients with metoprolol-associated adverse effects. Clin Pharmacol Ther 2002;72:429-37.

144. Lam YW, Gaedigk A, Ereshefsky L, Alfaro CL, Simpson J. CYP2D6 inhibition by selective serotonin reuptake inhibitors: analysis of achievable steady-state plasma concentrations and the effect of ultrarapid metabolism at CYP2D6. Pharmacotherapy 2002;22:1001-6.

145. Kirchheiner J, Nickchen K, Bauer M, Wong ML, Licinio J, Roots I, Brockmöller J. Pharmacogenetic of antidepressants and antipsychotics: the contribution of allelic variations to the phenotype of drug response. Mol Psychiatry 2004;9:44273.

146. Preskorn SH, Greenblatt DJ, Flockhart D, Luo Y, Perloff ES, Harmatz JS, Baker B, Klick-Davis A, Desta Z, Burt T. Comparison of duloxetine, escitalopram, and sertraline effects on cytochrome P450 2D6 function in healthy volunteers. J Clin Psychopharmacol 2007;27:28-34.

147. Stearns V, Johnson MD, Rae JM, Morocho A, Novielli A, Bhargava P, Hayes DF, Desta Z, Flockhart DA. Active tamoxifen metabolite plasma concentrations after coadministration of tamoxifen and the selective serotonin reuptake inhibitor paroxetine. J Natl Cancer Inst 2003;95:1758-64.

148. Gasche Y, Daali Y, Fathi M, Chiappe A, Cottini S, Dayer P, Desmeules J. Codeine intoxication associated with ultrarapid CYP2D6 metabolism. New Engl J Med 2004;351:2827-31.

149. Madadi P, Ross CJ, Hayden MR, Carleton BC, Gaedigk A, Leeder JS, Koren G. Pharmacogenetics of neonatal opioid toxicity following maternal use of codeine during breastfeeding: a case-control study. Clin Pharmacol Ther 2009;85:31-5.

150. Shen H, He MM, Liu H, Wrighton SA, Wang L, Guo B, Li C. Comparative metabolic capabilities and inhibitory profiles of CYP2D6.1, CYP2D6.10, and CYP2D6.17. Drug Metab Dispos 2007;35:1292-300.

151. Leclercq IA, Farrell GC, Field J, Bell DR, Gonzales FJ, Robertson GR. CYP2E1 and CYP4A as microsomal catalysts of lipid peroxides in murine nonalcoholic steatohepatitis. $\mathrm{J}$ Clin Invest 2000;105:1067-75.

152. Abdel-Razzak Z, Loyer P, Fautrel A, Gautier JC, Corcos L, Turlin B, Beaune P, Guillouzo A. Cytokines down-regulate expression of major cytochrome P-450 enzyme in adult human hepatocytes in primary culture. Mol Pharmacol 1993;44:707-15.

153. Kessova I, Cederbaum AI. CYP2E1: biochemistry, toxicology, regulation and function in ethanol-induced liver injury. Curr Mol Med 2003;3:509-18.

154. Villeneuve JP, Pichette V. Cytochrome P450 and liver diseases. Curr Drug Metab 2004;5:273-82.
155. Bolt HM, Roos PH, Thier R. The cytochrome P-450 isoenzyme CYP2E1 in the biological processing of industrial chemicals: consequences for occupational and environmental medicine. Int Arch Occup Environ Health 2003;76:174-85.

156. Yin H, Anders MW, Korzekwa KR, Higgins L, Thummel KE, Kharasch ED, Jones JP. Designing safer chemicals: predicting the rates of metabolism of halogenated alkanes. Proc Natl Acad Sci USA 1995;92:11076-80.

157. Gao CM, Takezaki T, Wu JZ, Chen MB, Liu YT, Ding JH, Sugimura H, Cao J, Hamajima N, Tajima K. CYP2E1 Rsa I polymorphism impacts on risk of colorectal cancer association with smoking and alcohol drinking. World J Gastroenterol 2007;13:5725-30.

158. Schindler J, Li Y, Marion MJ, Paroly A, Brandt-Rauf PW. The effect of genetic polymorphisms in the vinyl chloride metabolic pathway on mutagenic risk. J Hum Genet 2007;52:448-55.

159. Hsieh HI, Chen PC, Wong RH, Wang JD, Yang PM, Cheng TJ. Effect of the CYP2E1 genotype on vinyl chloride monomer-induced liver fibrosis among polyvinyl chloride workers. Toxicology 2007;239:34-44.

160. Zhu SM, Xia ZL, Wang AH, Ren XF, Jiao J, Zhao NQ, Qian J, Jin L, Christiani DC. Polymorphisms and haplotypes of DNA repair and xenobiotic metabolism genes and risk of DNA damage in Chinese vinyl chloride monomer (VCM)exposed workers. Toxicol Lett 2008;178:88-94.

161. Arif E, Vibhuti A, Alam P, Deepak D, Singh B, Athar M, Pasha MA. Association of CYP2E1 and NAT2 gene polymorphisms with chronic obstructive pulmonary disease. Clin Chim Acta 2007;382:37-42.

162. Zienolddiny S, Campa D, Lind H, Ryberg D, Skaug V, Stangeland LB, Canzian F, Haugen A. A comprehensive analysis of phase I and phase II metabolism gene polymorphisms and risk of non-small cell lung cancer in smokers. Carcinogenesis 2008;29:1164-9.

163. Zhou SF. Drugs behave as substrates, inhibitors and inducers of human cytochrome P450 3A4. Curr Drug Metab 2008;9:310-22.

164. Kapelyukh Y, Paine MJ, Maréchal JD, Sutcliffe MJ, Wolf CR, Roberts GC. Multiple substrate binding by cytochrome P450 3A4: estimation of the number of bound substrate molecules. Drug Metab Dispos 2008;36:2136-44.

165. Wrighton SA, Schuetz EG, Thummel KE, Shen DD, Korzekwa KR, Watkins PB. The human CYP3A subfamily: practical considerations. Drug Metab Rev 2000;32:339-61.

166. Kamdem LK, Meineke I, Gödtel-Armbrust U, Brockmöller J, Wojnowski L. Dominant contribution of P450 3A4 to the hepatic carcinogenic activation of aflatoxin B1. Chem Res Toxicol 2006;19:577-86.

167. Kale VM, Miranda SR, Wilbanks MS, Meyer SA. Comparative cytotoxicity of alachlor, acetochlor, and metolachlor herbicides in isolated rat and cryopreserved human hepatocytes. J Biochem Mol Toxicol 2008;22:4150 .

168. Guengerich FP. Cytochrome P-450 3A4: regulation and role in drug metabolism. Annu Rev Pharmacol Toxicol 1999;39:1-17.

169. Finta C, Zaphiropoulos PG. The human cytochrome P450 $3 \mathrm{~A}$ locus. Gene evolution by capture of downstream exons. Gene 2000;260:13-23.

170. Lacroix D, Sonnier M, Moncion A, Cheron G, Cresteil T. Expression of CYP3A in the human liver: evidence that the 
shift between CYP3A7 and CYP3A4 occurs immediately after birth. Eur J Biochem 1997;247:625-34.

171. Stevens JC, Hines RN, Gu C, Koukouritaki SB, Manro JR, Tandler PJ, Zaya MJ. Developmental expression of the major human hepatic CYP3A enzymes. J Pharmacol Exp Ther 2003;307:573-82.

172. Rodríguez-Antona C, Jande M, Rane A, Ingelman-Sundberg $M$. Identification and phenotype characterization of two CYP3A haplotypes causing different enzymatic capacity in fetal livers. Clin Pharmacol Ther 2005;77:259-70.

173. Buratti FM, Leoni C, Testai E. Foetal and adult human CYP3A isoforms in the bioactivation of organophosphorothionate insecticides. Toxicol Lett 2006;167:245-55.

174. Nivoix Y, Levêque D, Herbrecht R, Koffel JC, Beretz L, Ubeaud-Sequier G. The enzymatic basis of drug-drug interactions with systemic triazole antifungals. Clin Pharmacokinet 2008;47:779-92.

175. Zhang X, Jones DR, Hall SD. Prediction of the effect of erythromycin, diltiazem, and their metabolites, alone and in combination, on CYP3A4 inhibition. Drug Metab Dispos 2009;37:150-60

176. Kapelyukh Y, Paine MJ, Maréchal JD, Sutcliffe MJ, Wolf CR, Roberts GC. Multiple substrate binding by cytochrome P450 3A4: estimation of the number of bound substrate molecules. Drug Metab Dispos 2008;36:2136-44.

177. Moore LB, Goodwin B, Jones SA, Wisely GB, Serabjit-Singh CJ, Willson TM, Collins JL, Kliewer SA. St. John's wort induces hepatic drug metabolism through activation of the pregnane X receptor. Proc Natl Acad Sci USA 2000;97:75002.

178. Neuvonen PJ, Backman JT, Niemi M. Pharmacokinetic comparison of the potential over-the-counter statins simvastatin, lovastatin, fluvastatin and pravastatin. Clin Pharmacokinet 2008;47:463-74.

179. Ohno Y, Hisaka A, Ueno M, Suzuki H. General framework for the prediction of oral drug interactions caused by CYP3A4 induction from in vivo information. Clin Pharmacokinet 2008;47:669-80.

180. Spigset O, Molden E. Cytokrom P-450 3A4 - kroppens viktigste arena for legemiddelinteraksjoner Tidsskr Nor Laegeforen 2008;128:2832-5.

181. Westlind A, Lofberg L, Tindberg N, Andersson TB, Ingelman-Sundberg M. Interindividual differences in hepatic expression of CYP3A4: relationship to genetic polymorphism in the $5^{6}$-upstream regulatory region. Biochem Biophys Res Commun 1999;259:201-5.

182. Canaparo R, Finnström N, Serpe L, Nordmark A, Muntoni E, Eandi M, Rane A, Zara GP. Expression of CYP3A isoforms and P-glycoprotein in human stomach, jejunum and ileum. Clin Exp Pharmacol Physiol 2007;34:1138-44.

183. From MF. Genetically determined differences in Pglycoprotein function, implications for disease risk. Toxicology 2002;181-182:299-303.

184. Ieiri I, Hiroshi T, Otsubo K. The MDR1(ABCB1) gene polymorphism and its clinical implications. Clin Pharmacokinet 2004;43:553-76.

185. Geick A, Eichelbaum M, Burk O. Nuclear receptor response elements mediate induction of intestinal MDR1 by rifampin. J Biol Chem 2001;276:14581-7.

186. Olinga P, Elferink MG, Draaisma AL, Merema MT, Castell JV, Pérez G, Groothuis GM. Coordinated induction of drug transporters and phase I and II metabolism in human liver slices. Eur J Pharm Sci 2008;33:380-9.

187. Watkins PB. The barrier function of CYP3A4 and Pglycoprotein in the small bowel. Adv Drug Deliv Rev 1997;27:161-70.

188. Hesselink DA. Genetic polymorphisms of the CYP3A4, CYP3A5, and MDR1 genes and pharmacokinetics of the calcineurin inhibitors cyclosporine and tacrolimus. Clin Pharmacol Ther 2003;74:245-54.

189. von Richter O, Burk O, Fromm MF, Thon KP, Eichelbaum M, Kivistö KT. Cytochrome P450 3A4 and P-glycoprotein expression in human small intestinal enterocytes and hepatocytes: a comparative analysis in paired tissue specimens. Clin Pharmacol Ther 2004;75:172-83.

190. van Waterschoot RA, Rooswinkel RW, Wagenaar E, van der Kruijssen CM, van Herwaarden AE, Schinkel AH. Intestinal cytochrome $\mathrm{P} 4503 \mathrm{~A}$ plays an important role in the regulation of detoxifying systems in the liver. FASEB J 2009;23:22431.

191. Rodríguez-Antona C, Sayi JG, Gustafsson LL, Bertilsson L, Ingelman-Sundberg M. Phenotype-genotype variability in the human CYP3A locus as assessed by the probe drug quinine and analyses of variant CYP3A4 alleles. Biochem Biophys Res Commun 2005;338:299-305.

192. Urquhart BL, Tirona RG, Kim RB. Nuclear receptors and the regulation of drug-metabolizing enzymes and drug transporters: implications for interindividual variability in response to drugs. J Clin Pharmacol 2007;47:566-78.

193. Lamba J, Lamba V, Schuetz E. Genetic variants of PXR (NR1I2) and CAR (NR1I3) and their implications in drug metabolism and pharmacogenetics. Curr Drug Metab 2005;6:369-83.

194. Hustert E, Zibat A, Presecan-Siedel E, Eiselt R, Mueller R, Fuss C, Brehm I, Brinkmann U, Eichelbaum M, Wojnowski L, Burk O. Natural protein variants of pregnane $X$ receptor with altered transactivation activity toward CYP3A4. Drug Metab Dispos 2001;29:1454-9.

195. Rodríguez-Antona C, Jande M, Rane A, Ingelman-Sundberg M. Identification and phenotype characterization of two CYP3A haplotypes causing different enzymatic capacity in fetal livers. Clin Pharmacol Ther 2005;77:259-70.

196. Leeder JS, Gaedigk R, Marcucci KA, Gaedigk A, Vyhlidal CA, Schindel BP, Pearce RE. Variability of CYP3A7 expression in human fetal liver. J Pharmacol Exp Ther 2005;314:626-35.

197. Kuehl P, Zhang J, Lin Y, Lamba J, Assem M, Schuetz J, Watkins PB, Daly A, Wrighton SA, Hall SD, Maurel P, Relling M, Brimer C, Yasuda K, Venkataramanan R, Strom S, Thummel K, Boguski MS, Schuetz E. Sequence diversity in CYP3A promoters and characterization of the genetic basis of polymorphic CYP3A5 expression. Nat Genet 2001;27:38391.

198. Roberts PJ, Rollins KD, Kashuba AD, Paine MF, Nelsen AC, Williams EE, Moran C, Lamba JK, Schuetz EG, Hawke RL. The influence of CYP3A5 genotype on dexamethasone induction of CYP3A activity in African Americans. Drug Metab Dispos 2008;36:1465-9.

199. Daly AK. Significance of the minor cytochrome P450 3A isoforms. Clin Pharmacokinet 2006;45:13-31.

200. Hustert E, Haberl M, Burk O, Wolbold R, He YQ, Klein K, Nuessler AC, Neuhaus P, Klattig J, Eiselt R, Koch I, Zibat A, Brockmöller J, Halpert JR, Zanger UM, Wojnowski 
L. The genetic determinants of the CYP3A5 polymorphism. Pharmacogenetics 2001;11:773-9.

201. Lin YS, Dowling AL, Quigley SD, Farin FM, Zhang J, Lamba J, Schuetz EG, Thummel KE. Co-regulation of CYP3A4 and CYP3A5 and contribution to hepatic and intestinal midazolam metabolism. Mol Pharmacol 2002;62:162-72.

202. Anglicheau D, Legendre C, Beaune P, Thervet E. Cytochrome P450 3A polymorphisms and immunosuppressive drugs: an update. Pharmacogenomics 2007;8:835-49.

203. Crettol S, Venetz JP, Fontana M, Aubert JD, Pascual M, Eap CB. CYP3A7, CYP3A5, CYP3A4, and ABCB1 genetic polymorphisms, cyclosporine concentration, and dose requirement in transplant recipients. Ther Drug Monit 2008;30:689-99.

204. Iwasaki K. Metabolism of tacrolimus (FK506) and recent topics in clinical pharmacokinetics. Drug Metab Pharmacokinet 2007;22:328-35.

205. Keshava C, McCanlies EC, Weston A. CYP3A4 polymorphisms--potential risk factors for breast and prostate cancer: a HuGE review. Am J Epidemiol 2004;160:82541.

206. Vaarala MH, Mattila H, Ohtonen P, Tammela TL, Paavonen TK, Schleutker J. The interaction of CYP3A5 polymorphisms along the androgen metabolism pathway in prostate cancer. Int J Cancer 2008;122:2511-6.
207. Plummer SJ, Conti DV, Paris PL, Curran AP, Casey G, Witte JS. CYP3A4 and CYP3A5 genotypes, haplotypes, and risk of prostate cancer. Cancer Epidemiol Biomarkers Prev 2003;12:928-32.

208. Bangsi D, Zhou J, Sun Y, Patel NP, Darga LL, Heilbrun LK, Powell IJ, Severson RK, Everson RB. Impact of a genetic variant in CYP3A4 on risk and clinical presentation of prostate cancer among white and African-American men. Urol Oncol 2006;24:21-7.

209. Jin M, Gock SB, Jannetto PJ, Jentzen JM, Wong SH. Pharmacogenomics as molecular autopsy for forensic toxicology: genotyping cytochrome P450 3A4*1B and 3 A5*3 for 25 fentanyl cases. J Anal Toxicol 2005;29:5908.

210. U.S. Food and Drug Administration (FDA). Genomics at FDA. Available at http://www.fda.gov/cder/genomics.

211. de Leon J, Susce MT, Murray-Carmichael E. The AmpliChipCYP450 genotyping test: intergrating a new clinical tool. Mol Diagn Ther 2006;10:135-51.

212. Mendrick DL. Translational medicine: the discovery of bridging biomarkers using pharmacogenomics. Pharmacogenomics 2006;7:943-7. 
Sažetak

\title{
ULOGA GENSKOG POLIMORFIZMA METABOLIČKIH ENZIMA P450(CYP) KAO ČIMBENIKA OSJETLJIVOSTI NA UČINKOVITOST I TOKSIČNOST LIJEKA TE NASTANAK KARCINOMA
}

\begin{abstract}
Među enzimima I. faze biotransformacije sustav citokroma P450 (CYP) prednjači po katalitičkoj svestranosti i pokazuje vrlo visok stupanj polimorfnosti. Istraživanja polimorfizama gena CYP rezultirala su brojnim genetičkim informacijama koje nam pomažu u razumijevanju učinaka ksenobiotika na ljudski organizam. Ova superporodica enzima najvažniji je enzimski sustav uključen u biotransformaciju mnogih endogenih i egzogenih spojeva uključujući lijekove. Za metabolizam lijekova važan je polimorfizam CYP2C9, CYP2C19, CYP2D6 i CYP3A4/5 enzima. Među najvažnije izoforme odgovorne za biotransformaciju različitih kemijskih spojeva a posebno metaboličku aktivaciju prokarcinogena pripadaju CYP1A1, CYP1A2, CYP1B1, CYP2E1. Genska analiza ključnih enzima metabolizma lijekova pomaže u predviđanju terapijskog učinka ili razvoja štetnih nuspojava lijekova. Stoga primjena genotipizacije u kliničkoj praksi pomaže u optimizaciji i individualizaciji terapije i smanjenju medicinskih troškova. Polimorfizam metaboličkih enzima može imati važan učinak na terapiju antidepresivima, antipsihoticima, antikoagulantima, antidijabeticima, antitumorskim lijekovima te lijekovima za liječenje ulkusa i HIV-a. Podaci koje donosi toksikogenomika istražujući individualne predispozicije za karcinogene, teratogene i druge toksičke učinke ksenobiotika, pridonose rasvjetljavanju molekularnih mehanizama kojima kemijski spojevi iz okoliša ili na radnome mjestu utječu na nastanak bolesti u ljudi. Postoje značajni dokazi o povezanosti genskih polimorfizama i osjetljivosti za razvoj karcinoma. Metabolički putovi karcinogenih supstancija su kompleksni, posredovani aktivnošću različitih gena, dok pojedinačni geni najčešće imaju ograničen učinak. Stoga je multigenski pristup, uz uključivanje važnih čimbenika iz okoliša u studijama s velikim brojem ispitanika bitan za pouzdanu procjenu rizika od razvoja karcinoma.
\end{abstract}

KLJUČNE RIJEČI: citokromi P450, farmakogenomika, genotipizacija, individualizacija terapije, karcinogeneza, nuspojaveFirtin telabem diurnihiliam obsed se, C. Sp. Tum tatilnem nosultimis et auconcem audam sunum or la noximuloctus tudam ment.

\section{CORRESPONDING AUTHOR:}

Nada Božina

Klinički bolnički centar Zagreb

Klinički zavod za laboratorijsku dijagnostiku

Kišpatićeva 12, 10000 Zagreb

Email:nbozina@kbc-zagreb.hr 